Article

\title{
Pyridine-Ureas as Potential Anticancer Agents: Synthesis and In Vitro Biological Evaluation
}

\author{
Mohamed El-Naggar ${ }^{1}$, Hadia Almahli ${ }^{2,3}$, Hany S. Ibrahim ${ }^{3}{ }^{\mathbb{D}}$, Wagdy M. Eldehna ${ }^{4, *}$ and \\ Hatem A. Abdel-Aziz ${ }^{5}$ \\ 1 Chemistry Department, Faculty of Sciences, University of Sharjah, Sharjah 27272, UAE; \\ m5elnaggar@yahoo.com \\ 2 Department of Chemistry, Chemistry Research Laboratory, University of Oxford, 12 Mansfield Road, \\ Oxford OX1 3TA, UK; hadia.almahli@yahoo.com \\ 3 Department of Pharmaceutical Chemistry, Faculty of Pharmacy, Egyptian Russian University, Badr City, \\ Cairo 11829, Egypt; hany.s.ibrahim@gmail.com \\ 4 Department of Pharmaceutical Chemistry, Faculty of Pharmacy, Kafrelsheikh University, \\ Kafrelsheikh 33516, Egypt \\ 5 Department of Applied Organic Chemistry, National Research Center, Dokki, Cairo 12622, Egypt; \\ hatem_741@yahoo.com \\ * Correspondence: wagdy2000@gmail.com; Tel.: +20-1068837640
}

Academic Editors: Simona Collina and Mariarosaria Miloso

Received: 23 May 2018; Accepted: 12 June 2018; Published: 15 June 2018

\begin{abstract}
In our endeavor towards the development of effective anticancer agents, a novel series of pyridine-ureas 8a-n were synthesized. All the newly prepared derivatives were evaluated in vitro for their growth inhibitory activity towards the proliferation of breast cancer MCF-7 cell line. Compounds $8 \mathbf{e}$ and $8 \mathbf{n}$ were found to be the most active congeners against MCF-7 cells $\left(\mathrm{IC}_{50}=0.22\right.$ and $1.88 \mu \mathrm{M}$ after $48 \mathrm{~h}$ treatment; 0.11 and $0.80 \mu \mathrm{M}$ after $72 \mathrm{~h}$ treatment, respectively) with increased activity compared to the reference drug doxorubicin $\left(\mathrm{IC}_{50}=1.93 \mu \mathrm{M}\right)$. Moreover, eight selected pyridines $\mathbf{8 b}$, $\mathbf{8 d}, \mathbf{8 e}, \mathbf{8} \mathbf{i}, \mathbf{8 j}$ and $\mathbf{8 1}-\mathbf{n}$ were evaluated for their in vitro anticancer activity according to the US-NCI protocol. Pyridines $\mathbf{8 b}$ and $8 \mathbf{e}$ proved to be the most effective anticancer agents in the NCI assay with mean inhibition $=43$ and $49 \%$, respectively. Both $\mathbf{8 b}$ and $8 \mathbf{e}$ exhibited anti-proliferative activity

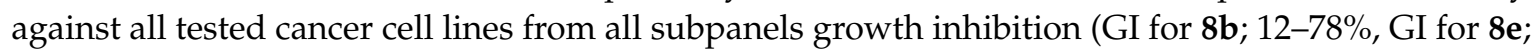
15-91\%). Pyridines $\mathbf{8 b}$ and $\mathbf{8 e}$ were screened in vitro for their inhibitory activity against VEGFR-2. Both compounds inhibited VEGFR-2 at micromolar $\mathrm{IC}_{50}$ values $5.0 \pm 1.91$ and $3.93 \pm 0.73 \mu \mathrm{M}$, respectively. The most active pyridines were filtered according to the Lipinski and Veber rules and all of them passed these filters. Finally, several ADME descriptors were predicted for the active pyridines through a theoretical kinetic study.
\end{abstract}

Keywords: pyridine-urea; breast cancer; anticancer; VEGFR-2; synthesis; ADME

\section{Introduction}

Cancer represents one of the most important health problems worldwide because it is deemed to be the second major cause of mortality throughout the world after cardiovascular diseases. The high mortality rate that occurs in cancer patients is due to the late diagnosis, and consequently the delayed initiation of the medical treatment of the disease. Although there are a large number of chemotherapeutic drugs available, the medical need is still largely unmet. According to the latest GLOBOCAN statistics, about 14.1 million newly diagnosed cancer cases were recorded. Among the newly diagnosed cases in females, breast cancer ranked in the first position worldwide and was regarded as the main cause of deaths attributed to cancer [1,2]. Accordingly, there is a pressing 
necessity to pay much effort to modify drug leads from the point of view of drug design to afford new bioactive chemical entities that offer improvements over current therapies.

In the current medical era, non-fused pyridines have emerged as a substantial class of heterocycles, which are endowed with diverse biological activities, chiefly anticancer activities [3-5]. Several pyridine-based small molecules have been approved as anticancer drugs, to name just a few: Sorafenib I (Nexavar ${ }^{\circledR}$, Figure 1), Regorafenib II (Stivarga ${ }^{\circledR}$, Figure 1), Vismodegib III (Erivedge ${ }^{\circledR}$, Figure 1) and Crizotinib IV (Xalkori ${ }^{\circledR}$, Figure 1) [6-8]. Subsequently, extensive efforts have been devoted to develop several pyridine-based derivatives as effective anticancer agents. BRN-103 V (Figure 1) is a nicotinamide derivative that suppresses the VEGF-induced phosphorylation of VEGFR-2 and the activation of AKT and eNOS. Also, it inhibits VEGF-induced migration, proliferation and capillary-like tube formation of HUVECs [9]. SKLB610 VI (Figure 1) is a multi-targeted kinase inhibitor activity towards VEGFR-2 and FGFR-2. SKLB610 has anti-proliferative effects, especially on human colorectal cancer cell line HCT-116 and human NSCLC cell line A549, with significant activity on tumor xenografts in nude mice without evident toxicity [10].

On the other hand, urea derivatives represent one of the most useful classes of anticancer agents, with a wide range of activities towards various tumors [11]. Urea functionality is the main pharmacophoric feature in several anticancer drugs such as Sorafenib I and Regorafenib II. Linifanib VII (Figure 1), an ureido indazole derivative, has selective inhibitory activity towards VEGFR and PDGFRs. Linifanib is in phase II clinical trials for patients with locally advanced or metastatic non-small cell lung cancer [12]. SLC-0111 VIII (Figure 1), an ureido benzenesulfonamide derivative, is currently in phase I/II clinical trials as a potential anticancer drug. SLC-0111 exhibited selectivity towards inhibition of the transmembrane isoforms human carbonic anhydrase (hCA) IX/XII (over the cytosolic isoforms hCA I/II). Also, SLC-0111 has the ability to block human breast cancer invasion, delay tumor growth and diminish the cancer stem cell population in vivo [13-16].

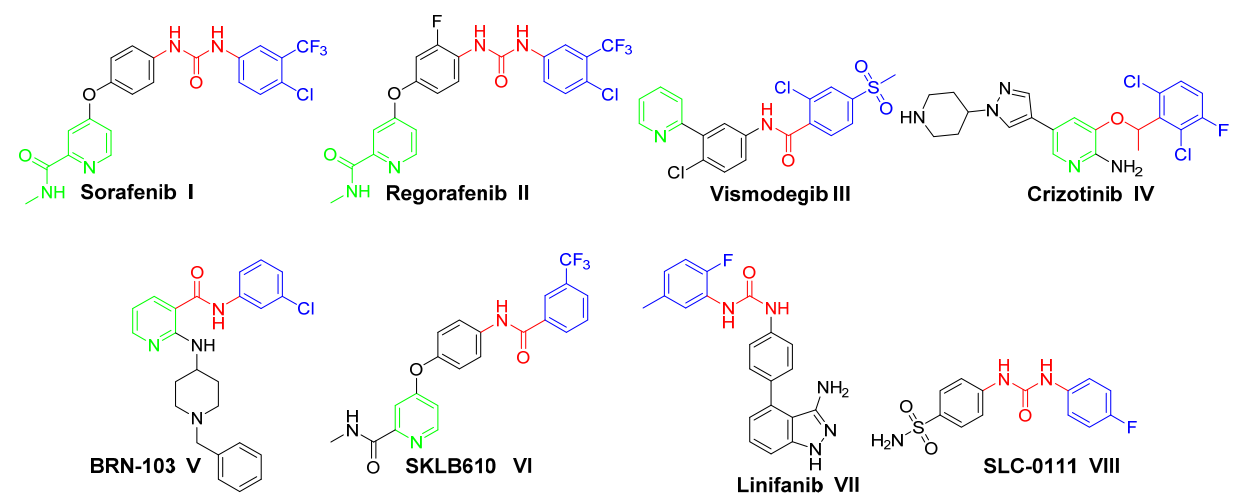

Figure 1. Structures of some pyridine-/urea-based approved anticancer drugs (I-IV), or in clinical trials (V-XIII), and the target conjugates $(\mathbf{4} \mathbf{a}-\mathbf{n}$ and $\mathbf{7 a}-\mathbf{d})$.

Recently, our research team has paid much attention to developing diverse novel small molecules, based on the pyridine core (structures IX and $\mathbf{X}$, Figure 2) or incorporating the ureido functionality (structures XI and XII, Figure 2), as potent anticancer agents. These molecules displayed promising anticancer activities through different molecular and enzymatic targets, such as cytotoxic action $[17,18]$, VEGFR-2 inhibition [19,20] or tumor-associated hCA isoform IX and XII inhibition [21].

Taking the above into account and as a continuation of our endeavor towards developing novel anticancer agents [22-25], it was thought worthwhile to extend our examinations to probe certain pyridine-urea derivatives displaying potent anticancer activity. In this study, a new series of pyridine-ureas 8a-n (Figure 2) was synthesized as potential anticancer agents. The latter synthesized pyridine-ureas were evaluated for their growth inhibitory activity towards the proliferation of breast cancer MCF-7 cell line. Moreover, eight selected pyridines $\mathbf{8 b}, \mathbf{8 d}, \mathbf{8 e}, \mathbf{8 i}, \mathbf{8 j}$ and $\mathbf{8 1 - n}$ were evaluated 
for their in vitro anticancer activity according to US-NCI protocol over 58 cancer cell lines. Moreover, the most active pyridines were screened in vitro for their inhibitory activity against VEGFR-2. Finally, several ADME descriptors were predicted for the active pyridines through a theoretical kinetic study.<smiles>[R][M]c1ccccc1-c1ccc(C(=O)NN=C2C(=O)Nc3ccc([X])cc32)c(C)n1</smiles><smiles>[R]c1ccc(NC(=O)Nc2ccc(Nc3nnc(Cc4ccc(OC)cc4)c4ccccc34)cc2)cc1</smiles><smiles>[R]c1ccc(NC(=O)Nc2ccc(/N=C3\C(=O)N([R1])c4ccc([X])cc43)cc2)cc1</smiles><smiles>[R]c1cc(-c2ccc(NC(=O)Nc3ccc(Br)cc3)c(C)n2)ccc1OC</smiles>

Figure 2. Structures of some pyridine-/urea-based anticancer agents reported by our research group (IX-XII), and the target pyridine-ureas 8a-n.

\section{Results}

\subsection{Chemistry}

The target pyridine-ureas $\mathbf{8 a}-\mathbf{n}$ were synthesized adopting the chemical pathway outlined in Scheme 1. In a one-pot three-component heterocyclocondensation process, ethyl 6-(4-methoxyphenyl) -2-methylnicotinate $3 \mathbf{a}$ and 6-(3,4-dimethoxyphenyl)-2-methylnicotinate $3 \mathbf{b}$ were prepared through the reaction of enaminones $\mathbf{2} \mathbf{a}, \mathbf{b}$ with ethyl acetoacetate and ammonium acetate in glacial acetic acid under reflux temperature. Hydrazinolysis of esters $\mathbf{3} \mathbf{a}, \mathbf{b}$ were achieved through refluxing with hydrazine hydrate in methanol to afford hydrazides $4 \mathbf{a}, \mathbf{b}$ in $80 \%$ and $86 \%$ yield, respectively. Stirring of hydrazides $\mathbf{4} \mathbf{a}, \mathbf{b}$ with sodium nitrite in glacial acetic acid in an ice bath furnished nicotinoyl azide $\mathbf{5 a}, \mathbf{b}$. Finally, preparation of pyridine-ureas $\mathbf{8 a}-\mathbf{n}$ were accomplished via addition of anilines $\mathbf{7 a - g}$ to a pre-heated solution of nicotinoyl azide $\mathbf{5 a}, \mathbf{b}$ in xylene, with good yields; $72-83 \%$ (Scheme 1).

Postulated structures of the newly synthesized pyridine-ureas $\mathbf{8 a - n}$ were in full agreement with their spectral and elemental analyses data (Supplementary Materials).

\subsection{Biological Evaluation}

\subsubsection{In Vitro Anti-Proliferative Activity}

The in vitro anti-proliferative activity of the newly prepared pyridine-ureas $\mathbf{8 a}-\mathbf{n}$ was examined against breast cancer MCF-7 cell line. The assay was carried out, as triplicates, utilizing the 3-(4,5-dimethylthiazol-2-yl)-2,5-diphenyltetrazolium bromide (MTT) colorimetric assay as described by T. Mosmann [26]. Doxorubicin and Sorafenib were included in this assay as a reference drug. The results were expressed as median growth inhibitory concentration $\left(\mathrm{IC}_{50}\right)$ values that represent the compound concentrations required to afford a 50\% inhibition of cell growth after 48 and $72 \mathrm{~h}$ of incubation, compared to the untreated controls (Table 1). 


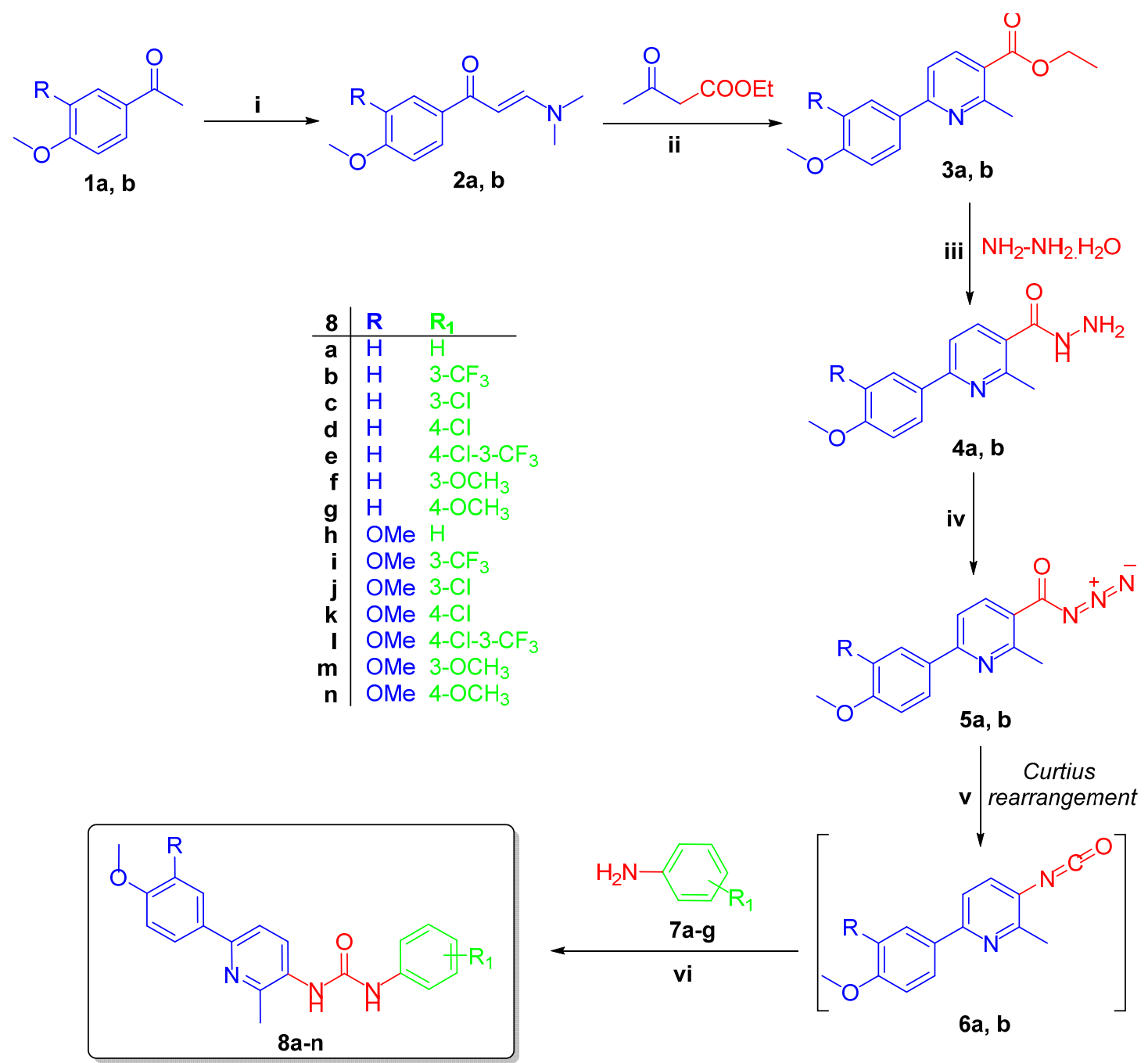

Scheme 1. Synthesis of target pyridine-ureas 8a-n; Reagents and conditions: (i) DMF-DMA, xylene, reflux 7hrs; (ii) $\mathrm{NH}_{4} \mathrm{OAc}, \mathrm{AcOH}$, reflux $4 \mathrm{~h}$; (iii) Methanol, $\mathrm{NH}_{2} \mathrm{NH}_{2} \cdot \mathrm{H}_{2} \mathrm{O}$, reflux $2 \mathrm{~h}$; (iv) $\mathrm{NaNO}_{2}$, AcOH, stirring $2 \mathrm{~h}$; (v) Xylene, reflux $1 \mathrm{~h}$; (vi) Xylene, reflux $3 \mathrm{~h}$.

From the obtained results, it was obvious that most of the prepared pyridine-ureas $\mathbf{8 a}-\mathbf{n}$ exhibited excellent to moderate anti-proliferative activity against MCF-7 breast cancer. Regarding the activity after $48 \mathrm{~h}$ treatment, compound $8 \mathbf{e}\left(\mathrm{IC}_{50}=0.22 \mu \mathrm{M}\right)$ was found to be the most potent derivative as it was 8.7 times more active than Doxorubicin $\left(\mathrm{IC}_{50}=1.93 \mu \mathrm{M}\right)$ and 20 times more than Sorafenib $\left(\mathrm{IC}_{50}=4.50 \mu \mathrm{M}\right)$. Also, compound $8 \mathrm{n}$ displayed excellent anti-proliferative activity against MCF-7 cells $\left(\mathrm{IC}_{50}=1.88 \mu \mathrm{M}\right)$ which is comparable to Doxorubicin and better than Sorafenib. Furthermore, pyridines $\mathbf{8 a}-\mathbf{d}, \mathbf{8 g}, \mathbf{8 i}, \mathbf{8 k}$ and $\mathbf{8 1}$ displayed potent activity against MCF-7 cells with $\mathrm{IC}_{50}$ range 3.03-7.03 $\mu \mathrm{M}$. Moreover, pyridines $\mathbf{8 j}$ and $\mathbf{8 m}$ were moderately active with $\mathrm{IC}_{50}$ values of 10.09 and $23.02 \mu \mathrm{M}$, respectively. Unfortunately, compounds $\mathbf{8 f}$ and $\mathbf{8 h}$ did not display significant activity towards MCF-7 cells $\left(\mathrm{IC}_{50}>50 \mu \mathrm{M}\right)$.

On the other hand, investigation of the anti-proliferative activity towards MCF-7 cells at $72 \mathrm{~h}$ of treatment elucidated that compounds $\mathbf{8 g}, \mathbf{8 j}$ and $\mathbf{8 1}$ possessed higher activity at $72 \mathrm{~h}$ compared to $48 \mathrm{~h}$. The drop in activity after longer incubation time, $72 \mathrm{~h}$, could be explained by the rapid metabolism for such compounds or that the tested MCF-7 cells were resistant to compounds $8 \mathbf{g}, 8 \mathbf{j}$ and 81 upon $72 \mathrm{~h}$ treatment. With an exception of compound $8 \mathrm{~m}\left(\mathrm{IC}_{50}=13.1 \mu \mathrm{M}\right)$ and compounds $\mathbf{8 f}$ and $\mathbf{8 h}$ $\left(\mathrm{IC}_{50}>50 \mu \mathrm{M}\right)$, all the tested pyridines possessed potent activity against MCF-7 cells with $\mathrm{IC}_{50}$ range 0.11-5.14 $\mu \mathrm{M}$, upon $72 \mathrm{~h}$ treatment. 
Table 1. In vitro anti-proliferative activity of pyridine-ureas 8a-n against MCF-7 breast cancer cell line.

\begin{tabular}{|c|c|c|c|c|}
\hline & \multicolumn{2}{|c|}{ (c) } & & \\
\hline \multirow{2}{*}{ Compound } & \multirow{2}{*}{$\mathbf{R}$} & \multirow{2}{*}{$\mathbf{R}_{1}$} & \multicolumn{2}{|c|}{$\mathrm{IC}_{50}(\mu \mathrm{M})^{\mathrm{a}}$} \\
\hline & & & $48 \mathrm{~h}$ & $72 \mathrm{~h}$ \\
\hline $8 a$ & $\mathrm{H}$ & $\mathrm{H}$ & $3.03 \pm 0.22$ & $2.83 \pm 0.25$ \\
\hline $8 b$ & $\mathrm{H}$ & $3-\mathrm{CF}_{3}$ & $5.66 \pm 0.45$ & $5.03 \pm 0.29$ \\
\hline $8 c$ & $\mathrm{H}$ & $3-\mathrm{Cl}$ & $6.40 \pm 0.41$ & $3.52 \pm 0.11$ \\
\hline $8 d$ & $\mathrm{H}$ & $4-\mathrm{Cl}$ & $7.10 \pm 0.38$ & $5.14 \pm 0.46$ \\
\hline $8 \mathrm{e}$ & $\mathrm{H}$ & $4-\mathrm{Cl}-3-\mathrm{CF}_{3}$ & $0.22 \pm 0.02$ & $0.11 \pm 0.1$ \\
\hline $8 f$ & $\mathrm{H}$ & $3-\mathrm{OCH}_{3}$ & $\mathrm{NA}^{\mathrm{b}}$ & $\mathrm{NA}^{\mathrm{b}}$ \\
\hline $8 \mathrm{~g}$ & $\mathrm{H}$ & $4-\mathrm{OCH}_{3}$ & $4.12 \pm 0.27$ & $27.24 \pm 1.98$ \\
\hline $8 \mathrm{~h}$ & $\mathrm{OCH}_{3}$ & $\mathrm{H}$ & $\mathrm{NA}^{\mathrm{b}}$ & $\mathrm{NA}^{\mathrm{b}}$ \\
\hline $8 i$ & $\mathrm{OCH}_{3}$ & $3-\mathrm{CF}_{3}$ & $6.19 \pm 0.54$ & $5.80 \pm 0.34$ \\
\hline $8 j$ & $\mathrm{OCH}_{3}$ & $3-\mathrm{Cl}$ & $10.9 \pm 1.03$ & $26.2 \pm 2.17$ \\
\hline $8 k$ & $\mathrm{OCH}_{3}$ & 4-Cl & $5.63 \pm 0.36$ & $3.45 \pm 0.30$ \\
\hline 81 & $\mathrm{OCH}_{3}$ & $4-\mathrm{Cl}-3-\mathrm{CF}_{3}$ & $7.03 \pm 0.61$ & $21.43 \pm 2.03$ \\
\hline $8 m$ & $\mathrm{OCH}_{3}$ & $3-\mathrm{OCH}_{3}$ & $23.02 \pm 1.91$ & $13.1 \pm 1.12$ \\
\hline $8 \mathrm{n}$ & $\mathrm{OCH}_{3}$ & $4-\mathrm{OCH}_{3}$ & $1.88 \pm 0.12$ & $0.80 \pm 0.07$ \\
\hline Dox. & - & - & $1.93 \pm 0.15$ & $1.07 \pm 0.07$ \\
\hline Sorafenib & - & - & $4.50 \pm 0.30$ & $1.71 \pm 0.15$ \\
\hline
\end{tabular}

${ }^{\mathrm{a}} \mathrm{IC}_{50}$ values are the mean \pm S.D. of three separate experiments; ${ }^{\mathrm{b}}$ NA: Compounds having $\mathrm{IC}_{50}$ value $>50 \mu \mathrm{M}$.

\subsubsection{NCI, USA Cytotoxicity Assay towards 60 Cancer Cell Lines}

The structures of all the newly prepared pyridine-ureas $8 \mathbf{a}-\mathbf{n}$ were submitted to the National Cancer Institute (NCI) Developmental Therapeutic Program. Eight compounds 8b, 8d, 8e, 8i, $\mathbf{8 j}$ and 81-n were selected to be examined for their in vitro growth inhibitory activity. The anticancer assays were carried out according to the protocol of the Drug Evaluation Branch, NCI, Bethesda [27-29]. The selected pyridine-ureas were tested at one dose primary anticancer assay against a panel of approximately 58 cancer lines (concentration $10^{-5} \mathrm{M}$ ). The tested human cancer cell lines emerged from nine different cancer subtypes: leukemia, colon, melanoma, ovarian, lung, CNS, renal, breast and prostate cancers. The sulforhodamine B (SRB) protein assay was adopted to estimate the cell viability and growth [30]. The results were reported as mean-graph of the percentage growth of the treated cells, and presented as percentage growth inhibition (GI\%) caused by the test compounds (Table 2). The gained data disclosed that most tested pyridines possessed distinctive patterns of selectivity and sensitivity towards the different NCI cancer cell panels (Supplementary Material).

The obtained GI\% values (Table 2), showed that pyridine $8 \mathbf{e}$ was found to be the most active member in this study with mean inhibition $=49 \%$, Figure 3. Compound 8e exhibited anti-proliferative activity against all tested cancer cell lines from all subpanels (GI; 15-91\%) with a potent growth inhibitory effect over leukemia K-562, MOLT-4 and RPMI-8226, non-small cell lung cancer NCI-H522, colon cancer HCT-116, prostate cancer PC-3 and breast cancer T-47D with inhibition \% 84, 76, 91, 76, 77, 86 and 79, respectively. Moreover, compound $\mathbf{8 b}$ emerged as the second most active analogue (mean inhibition range $=43 \%$, Figure 3 ) with good activity against all cell lines (GI; $12-78 \%$ ) except the ovarian cancer IGROV1 cell line. Additionally, pyridines $8 \mathbf{i}, \mathbf{8 j}, \mathbf{6 1}$, and $8 \mathbf{n}$ showed moderate growth inhibitory activities (mean inhibition range: $22-34 \%$, Figure 3) with a distinctive pattern of selectivity and sensitivity against different $\mathrm{NCI}$ cancer cell lines. Nevertheless, pyridines $\mathbf{8} \mathbf{d}$ and $\mathbf{8 m}$ possessed fair and selective growth inhibitory activities (mean inhibition range $=14$ and $8 \%$, respectively, Figure 3 ) towards sporadic cell lines. Notably, compound $\mathbf{8 m}$ did not show any significant activity against the cell lines of CNS and ovarian subpanels. 
Table 2. Percentage growth inhibition (GI\%) of in vitro subpanel tumor cell lines at $10 \mu \mathrm{M}$ concentration for compounds $8 b, 8 d, 8 e, 8 i, 8 j$ and $81-n$.

\begin{tabular}{|c|c|c|c|c|c|c|c|c|c|}
\hline \multirow{2}{*}{\multicolumn{2}{|c|}{ Subpanel/Cell Line }} & \multicolumn{8}{|c|}{ Compound $^{a}$} \\
\hline & & $\begin{array}{c}8 b \text { (NSC } \\
793907)\end{array}$ & $\begin{array}{c}\text { 8d (NSC } \\
793908)\end{array}$ & $\begin{array}{c}\text { 8e (NSC } \\
793925)\end{array}$ & $\begin{array}{c}8 \mathrm{i} \text { (NSC } \\
793919)\end{array}$ & $\begin{array}{c}8 \mathrm{j} \text { (NSC } \\
793924)\end{array}$ & $\begin{array}{c}81 \text { (NSC } \\
793915)\end{array}$ & $\begin{array}{c}\text { 8m (NSC } \\
793929)\end{array}$ & $\begin{array}{c}\text { 8n (NSC } \\
793926)\end{array}$ \\
\hline \multirow{6}{*}{ 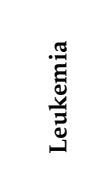 } & CCRF-CEM & 58 & 19 & 71 & 50 & 32 & 45 & 11 & - \\
\hline & HL-60(TB) & 51 & 21 & 68 & 39 & 37 & 48 & 27 & 15 \\
\hline & K-562 & 68 & 16 & 84 & 69 & 60 & 51 & 22 & 27 \\
\hline & MOLT-4 & 67 & 28 & 76 & 61 & 58 & 57 & 35 & 15 \\
\hline & RPMI-8226 & 78 & 10 & 91 & 66 & 49 & 57 & 26 & 17 \\
\hline & SR & 64 & 57 & 65 & 49 & 48 & 40 & 18 & 43 \\
\hline \multirow{9}{*}{ 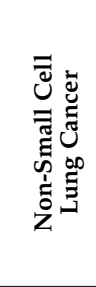 } & A549/ATCC & 58 & 32 & 62 & 40 & 39 & 56 & 10 & 43 \\
\hline & EKVX & 59 & - & 51 & 34 & 17 & 33 & - & - \\
\hline & HOP-62 & 33 & 19 & 38 & - & 23 & 23 & - & 44 \\
\hline & HOP-92 & 32 & 19 & 73 & 45 & 40 & 30 & 19 & 27 \\
\hline & NCI-H226 & 42 & - & 35 & 28 & - & 28 & - & 42 \\
\hline & NCI-H23 & 53 & - & 70 & 29 & 11 & 29 & 10 & 33 \\
\hline & NCI-H322M & 36 & 35 & 29 & - & 15 & 13 & - & 14 \\
\hline & NCI-H460 & 52 & 36 & 70 & 39 & 17 & 48 & - & 83 \\
\hline & NCI-H522 & 72 & 33 & 76 & 60 & 41 & 57 & 47 & 51 \\
\hline \multirow{7}{*}{ 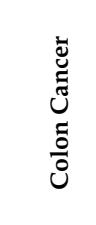 } & COLO 205 & 16 & - & 20 & 12 & - & - & - & - \\
\hline & HCC-2998 & 19 & - & 31 & 16 & 12 & - & - & 17 \\
\hline & HCT-116 & 74 & 24 & 77 & 83 & 37 & 55 & 22 & 51 \\
\hline & HCT-15 & 60 & 15 & 63 & 52 & 40 & 51 & - & - \\
\hline & HТ29 & 53 & 15 & 54 & 41 & 26 & 44 & 25 & 32 \\
\hline & KM12 & 55 & - & 63 & 34 & 22 & 30 & - & 55 \\
\hline & SW-620 & 19 & 23 & 33 & - & - & 10 & - & 36 \\
\hline \multirow{6}{*}{ 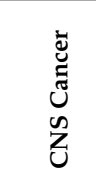 } & SF-268 & 26 & - & 27 & 25 & 13 & 25 & - & 41 \\
\hline & SF-295 & 53 & - & 54 & 35 & 17 & 29 & - & - \\
\hline & SF-539 & 20 & 16 & 19 & 23 & 11 & 13 & - & 30 \\
\hline & SNB-19 & 33 & - & 43 & 22 & - & 22 & - & 29 \\
\hline & SNB-75 & 23 & 16 & 27 & 34 & 16 & 20 & - & 53 \\
\hline & U251 & 50 & 24 & 67 & 37 & 17 & 45 & - & 78 \\
\hline & LOX IMVI & 53 & 15 & 36 & 30 & 20 & 22 & - & 12 \\
\hline & MALME-3M & 10 & - & 18 & - & - & 10 & - & 56 \\
\hline & M14 & 63 & 14 & 69 & 69 & 50 & 53 & 10 & 28 \\
\hline ๕̆ & MDA-MB-435 & 31 & 12 & 29 & 27 & 13 & 23 & - & 35 \\
\hline ఏ & SK-MEL-2 & 25 & - & 38 & 27 & 16 & 13 & 13 & 21 \\
\hline$\stackrel{\widetilde{g}}{2}$ & SK-MEL-28 & 31 & 11 & 29 & 25 & 21 & 27 & - & 14 \\
\hline & SK-MEL-5 & 59 & 13 & 45 & 42 & 32 & 37 & 16 & 78 \\
\hline & UACC-257 & 39 & 22 & 43 & 19 & 29 & 44 & - & 45 \\
\hline & UACC-62 & 37 & 29 & 35 & 19 & 25 & 23 & - & 41 \\
\hline & IGROV1 & - & 17 & 48 & - & - & 17 & - & 23 \\
\hline 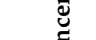 & OVCAR-3 & 59 & - & 73 & 31 & 10 & 43 & - & - \\
\hline త్ & OVCAR-4 & 58 & 26 & 55 & 41 & - & 25 & - & 71 \\
\hline$\Xi$ & OVCAR-5 & 17 & - & 11 & - & 12 & 15 & - & - \\
\hline . & OVCAR-8 & 39 & - & 43 & 19 & 10 & 19 & - & 53 \\
\hline กี & NCI/ADR-RES & 47 & - & 51 & 34 & 16 & 31 & - & 16 \\
\hline 0 & SK-OV-3 & 18 & 18 & 32 & - & 17 & 16 & - & 26 \\
\hline & $786-0$ & 23 & 10 & 44 & 31 & 29 & 25 & - & 89 \\
\hline ֻே & A498 & 48 & 21 & 43 & 39 & 31 & 43 & 15 & 29 \\
\hline తే & RXF 393 & 15 & - & 19 & 23 & 18 & 28 & - & 42 \\
\hline ส & SN12C & 33 & - & 43 & 21 & 14 & 22 & - & 36 \\
\hline Еี & TK-10 & 24 & - & 35 & 21 & - & 12 & - & 40 \\
\hline$\simeq$ & UO-31 & 45 & 11 & 61 & 26 & 21 & 28 & 20 & 19 \\
\hline I & PC-3 & 76 & 24 & 86 & 73 & 61 & 67 & 41 & 19 \\
\hline 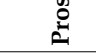 & DU-145 & 32 & - & 46 & 18 & - & 20 & - & 28 \\
\hline & MCF7 & 59 & 26 & 64 & 38 & 25 & 42 & 10 & 35 \\
\hline$\stackrel{\mathscr{\Xi}}{\Xi}$ & MDA-MB-231 & 32 & - & 15 & 31 & 13 & 12 & - & 60 \\
\hline లี & HS 578T & 12 & - & 24 & 26 & - & 19 & - & 61 \\
\hline$\vec{\omega}$ & BT-549 & 34 & - & 34 & 29 & - & 12 & 13 & 50 \\
\hline ळँ & $\mathrm{T}-47 \mathrm{D}$ & 74 & 28 & 79 & 47 & 51 & 51 & 19 & 40 \\
\hline $\bar{\emptyset}$ & MDA-MB-468 & 73 & - & 62 & 51 & 29 & 52 & - & 17 \\
\hline
\end{tabular}

${ }^{a}$ Only GI $\%$ higher than $10 \%$ are shown. 


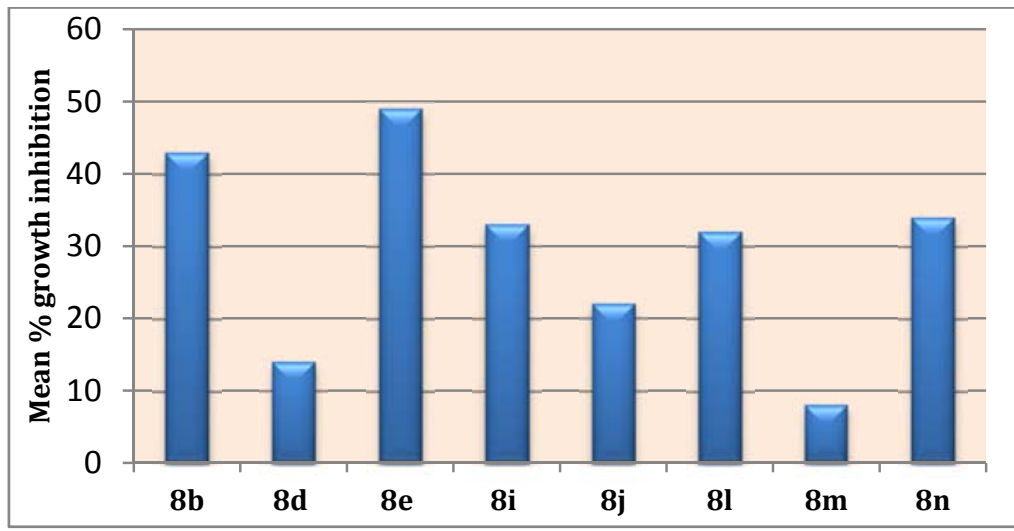

Figure 3. Mean \% growth inhibitions of the tested pyridines over NCI 58 cell line panel.

Interestingly, all cell lines of the leukemia subpanel were sensitive to all the tested pyridines $\mathbf{8 b}, \mathbf{8 d}, \mathbf{8 e}, \mathbf{8 i}, \mathbf{8 j}$ and 81-n (GI; 10-91\%), except for compound $\mathbf{8 n}$ towards CCRF-CEM cells. Besides, non-small cell lung cancer (A549 / ATCC, HOP-92 and NCI-H522), colon cancer (HCT-116 and HT29), melanoma (M14 and SK-MEL-5), renal cancer (A498 and UO-31), prostate cancer (PC-3) and breast cancer (T-47D and MCF7) were susceptible cell lines to all the screened compounds. The most sensitive cell lines towards the target pyridines were displayed in Figure 4A,B.
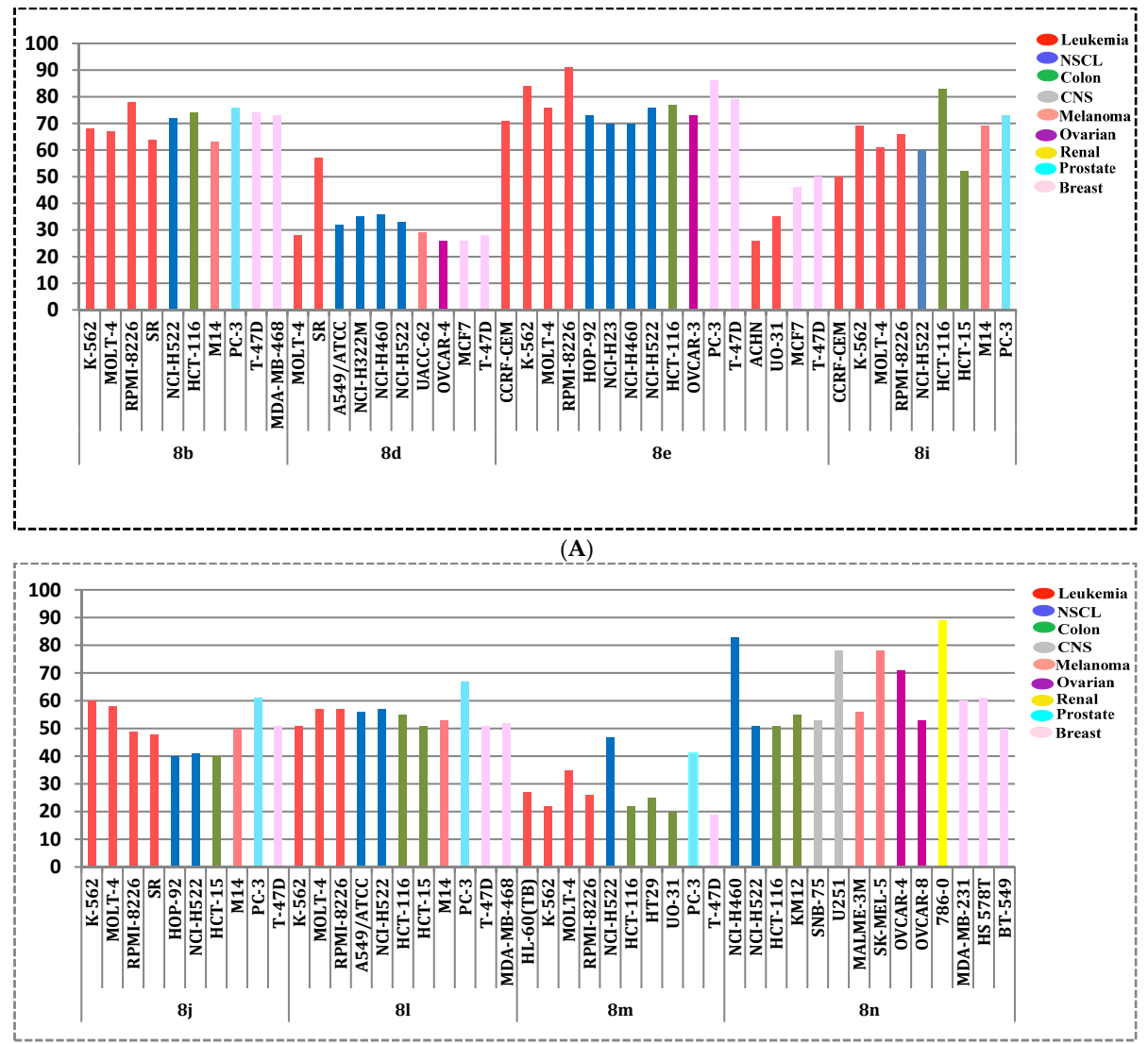

(B)

Figure 4. (A) The most sensitive cell lines towards the target pyridines $\mathbf{8 b}, \mathbf{8 d}, \mathbf{8 e}$ and $\mathbf{8 i}$ according to the GI\%; (B) the most sensitive cell lines towards the target pyridines $8 \mathbf{j}, 8 \mathbf{8 1}, 8 \mathrm{~m}$ and $8 \mathrm{n}$ according to the GI\%. 


\subsubsection{Cytotoxic Activity against Non-Tumorigenic Human WI-38 Cells}

The cytotoxic activity of compounds $\mathbf{8 b}$ and $\mathbf{8 e}$ were evaluated against non-tumorigenic human lung fibroblast WI-38 cell line utilizing the MTT colorimetric assay developed by T. Mosmann [26] (Table 3). Interestingly, both the tested compounds $\mathbf{8 b}$ and $\mathbf{8 e}$ displayed non-significant weak cytotoxic activity towards WI-38 cell line with $\mathrm{IC}_{50}$ values of $91.5 \pm 4.53$ and $83.14 \pm 5.21 \mu \mathrm{M}$, respectively.

Table 3. Cytotoxic activity of compounds $\mathbf{8 b}$ and $\mathbf{8 e}$ against non-tumorigenic human lung fibroblast WI-38 cell line.

\begin{tabular}{cc}
\hline \multirow{2}{*}{ Compound } & $\mathrm{IC}_{\mathbf{5 0}}(\boldsymbol{\mu M})^{\mathrm{a}}$ \\
\cline { 2 - 2 } & $\mathbf{W I}-\mathbf{3 8}$ \\
\hline $\mathbf{8 b}$ & $91.5 \pm 4.53$ \\
$\mathbf{8 e}$ & $83.14 \pm 5.21$ \\
\hline
\end{tabular}

${ }^{\mathrm{a}} \mathrm{IC}_{50}$ values are the mean \pm S.D. of three separate experiments.

\subsubsection{VEGFR-2 Inhibitory Assay}

In an attempt to gain further mechanistic insights for the promising anti-proliferative activity of the prepared pyridine-ureas, compounds $\mathbf{8 b}$ and $\mathbf{8 e}$, with significant anti-proliferative activity, were evaluated in vitro for their VEGFR-2 inhibitory activity. Sorafenib, a pyridine urea-based and well-known FDA-approved VEGFR-2 inhibitor, was used as the reference drug. The results are reported as median inhibition concentrations $\left(\mathrm{IC}_{50}\right)$ which are determined as triplicate determinations from the standard curve and listed in Table 4.

Table 4. IC $_{50}$ values for the inhibitory activity of pyridine-urea $\mathbf{8 e}$ and $\mathbf{8 n}$ against VEGFR-2.

\begin{tabular}{|c|c|}
\hline \multirow{2}{*}{ Compound } & $\mathrm{IC}_{50}(\mu \mathrm{M})^{\mathrm{a}}$ \\
\hline & VEGFR-2 \\
\hline $8 b$ & $5.00 \pm 1.91$ \\
\hline $8 e$ & $3.93 \pm 0.73$ \\
\hline Sorafenib & $0.09 \pm 0.01$ \\
\hline
\end{tabular}

Results revealed that the tested pyridines $\mathbf{8 b}$ and $\mathbf{8 e}$ exhibited modest VEGFR-2 inhibitory activity with $\mathrm{IC}_{50}$ values of $5.0 \pm 1.91$ and $3.93 \pm 0.73 \mu \mathrm{M}$, respectively, with respect to the reference drug Sorafenib $\left(\mathrm{IC}_{50}=0.09 \pm 0.01 \mu \mathrm{M}\right)$.

\subsection{Physicochemical Properties and ADME Profiling}

With a view to investigate drug-like physicochemical and pharmacokinetics properties of the target pyridine-ureas, several ADME descriptors for the active pyridines $(\mathbf{8} \mathbf{a}, \mathbf{8 b}, \mathbf{8 e}, \mathbf{8 g}, \mathbf{8} \mathbf{i}, \mathbf{8 1}$ and $8 \mathbf{n})$ were estimated, in addition to the assessment of the criteria of both the Lipinski rule of five [31] and Veber rule [32]. A computer-aided theoretical kinetic study was performed via Discovery Studio 2.5 software (Accelrys, San Diego, CA, USA) to estimate different ADME descriptors for the most active anti-proliferative pyridines $\mathbf{8 a}, \mathbf{8 b}, \mathbf{8 e}, \mathbf{8 g}, \mathbf{8} \mathbf{i}, \mathbf{8 1}$ and $\mathbf{8 n}$, Table 5 .

All the tested pyridines exhibited low aqueous solubility levels along with a good level of human intestinal absorption. Regarding blood-brain barrier penetration, the tested pyridines were discovered to possess certain penetrability to the blood-brain barrier. On the other hand, the investigated pyridines passed the filter of both the Lipinski rule of five and Veber rule, which implies that the synthesized pyridines have the privilege to possess good oral bioavailability, Table 6. 
Table 5. ADME studies results for all the synthesized compounds.

\begin{tabular}{cccccc}
\hline Compound & $\begin{array}{c}\text { ADMET } \\
\text { solubility }^{\mathbf{1}}\end{array}$ & $\begin{array}{c}\text { ADMET } \\
\text { Solubility Level }^{\mathbf{2}}\end{array}$ & $\begin{array}{c}\text { ADMET } \\
\text { Absorption Level }\end{array}$ & ADMET BBB $^{\mathbf{4}}$ & $\begin{array}{c}\text { ADMET } \\
\text { BBB Level }^{4}\end{array}$ \\
\hline $\mathbf{8 a}$ & -4.499 & 2 & 0 & -0.045 & 2 \\
$\mathbf{8 b}$ & -5.93 & 2 & 0 & 0.247 & 1 \\
$\mathbf{8 e}$ & -6.698 & 1 & 0 & 0.452 & 1 \\
$\mathbf{8 g}$ & -4.554 & 2 & 0 & -0.191 & 2 \\
$\mathbf{8 i}$ & -5.971 & 2 & 0 & 0.10 & 1 \\
$\mathbf{8}$ & -6.723 & 1 & 0 & 0.306 & 1 \\
$\mathbf{8 n}$ & -4.623 & 2 & 0 & -0.337 & 2 \\
\hline
\end{tabular}

${ }^{1}$ The base 10 logarithm of the molar solubility as predicted by the regression model based by DS; ${ }^{2}$ Categorical solubility level. $(0=$ extreme low, $1=$ very low but possible, $2=$ low, $3=$ good, $4=$ optimal $) ;{ }^{3}$ Human intestinal absorption level. $(0=$ good, $1=$ moderate, $2=$ poor, $3=$ very poor $) ;{ }^{4}$ Blood brain barrier penetration. $(0 ; \geq 0.7=$ very high penetrant, $1 ; 0 \leq \log \mathrm{BB}<0.7=$ High penetrant, $2 ;-0.52<\operatorname{LogBB}<0=\operatorname{low}, 3 ; \log B \mathrm{~B} \leq$ $-0.52=$ low, $4 ; \mathrm{NA}=$ undefined).

Table 6. Lipinski rule of five parameters results for all the synthesized compounds.

\begin{tabular}{|c|c|c|c|c|c|c|}
\hline Compound & $\begin{array}{l}\text { H-Bond } \\
\text { Donor }{ }^{1, *}\end{array}$ & $\begin{array}{c}\text { H-Bond } \\
\text { Acceptor }\end{array}$ & $\begin{array}{l}\text { Molecular } \\
\text { Weight }^{3}\end{array}$ & $A \log P^{4}$ & $\begin{array}{c}\text { No. of } \\
\text { Rotatable Bond }{ }^{5}\end{array}$ & $\begin{array}{c}\text { Polar Surface } \\
\text { Area }{ }^{6}\left(\AA^{2}\right)\end{array}$ \\
\hline $8 a$ & 2 & 3 & 333.38 & 3.585 & 4 & 63.25 \\
\hline $8 b$ & 2 & 3 & 401.38 & 4.527 & 5 & 63.25 \\
\hline $8 \mathrm{e}$ & 2 & 3 & 435.82 & 5.192 & 5 & 63.25 \\
\hline $8 \mathrm{~g}$ & 2 & 4 & 363.41 & 3.569 & 5 & 72.48 \\
\hline $8 \mathrm{i}$ & 2 & 4 & 431.41 & 4.511 & 6 & 72.48 \\
\hline 81 & 2 & 4 & 465.85 & 5.175 & 6 & 72.48 \\
\hline $8 n$ & 2 & 5 & 393.44 & 3.552 & 6 & 81.71 \\
\hline
\end{tabular}

${ }^{1}$ The upper limit of the number of hydrogen bond donors is $5 ;^{2}$ the upper limit of the number of hydrogen bond acceptors is $10 ;{ }^{3}$ the upper limit of the molecular weight is $500 ;{ }^{4}$ the upper limit of the AlogP (the $\log$ value of octanol-water partition coefficient) is $500 ;{ }^{5}$ the upper limit of the number of rotatable bonds is $10 ;^{6}$ the upper limit of the polar surface area is $140 \AA^{2}$; * the upper limit of the sum of the hydrogen bond donors and acceptors is 12 .

\section{Experimental}

\subsection{Chemistry}

Melting points were measured with a Stuart melting point apparatus (Bibby Scientific Limited, Staffordshire, UK) and were uncorrected. Infrared measurements (neat, thin film) were carried out using Schimadzu FT-IR $8400 \mathrm{~S}$ spectrophotometer (Shimadzu, Kyoto, Japan). ${ }^{1} \mathrm{H}-\mathrm{NMR}$ and ${ }^{13} \mathrm{C}-\mathrm{NMR}$ experiments were carried out using Bruker AVF-400 (400/100 MHz) and AVC-500 (500/125 MHz) (Bruker, Karlsruhe, Germany), respectively. Chemical shifts $\left(\delta_{\mathrm{H}}\right)$ are reported relative to TMS as the internal standard. All coupling constant $(J)$ values are given in hertz. Chemical shifts $\left(\delta_{C}\right)$ were reported as follows: s, singlet; $d$, doublet; $m$, multiplet. High-resolution mass spectra (EI and ESI) were recorded using a Bruker MicroTOF spectrometer (Bruker Daltonics, Bremen, Germany) by the internal service at the University of Oxford. Analytical thin layer chromatography (TLC) (Merck KGaA, Darmstadt, Germany) on silica gel plates containing UV indicator was employed routinely to follow the course of reactions and to check the purity of products. All reagents and solvents were purified and dried by standard techniques. Compounds $\mathbf{2} \mathbf{a}, \mathbf{b}, \mathbf{3} \mathbf{a}, \mathbf{b}$, and $\mathbf{4 a}, \mathbf{b}[17,33]$ were previously prepared.

\subsubsection{Synthesis of 6-(4-Methoxyphenyl/3,4-dimethoxyphenyl)-2-methylnicotinohydrazide $4 \mathbf{a}, \mathbf{b}$}

To a suspension of esters $\mathbf{3 a}, \mathbf{b}(10 \mathrm{mmol})$ in methyl alcohol, $99 \%$ hydrazine hydrate $(3 \mathrm{~mL})$ was added. The reaction mixture was heated under reflux for $2 \mathrm{~h}$. The precipitate formed was collected by filtration while hot, washed with water, dried and recrystallized from ethanol to produce hydrazides $\mathbf{4 a}, \mathbf{b}$ in $80 \%$ and $86 \%$ yield, respectively. The physical properties and spectral data of $\mathbf{4 a}, \mathbf{b}$ were identical with those reported [28]. 


\subsubsection{General Procedure for the Preparation of Target Pyridine-Ureas 8a-n}

In an ice bath, a mixture of hydrazides $4 \mathbf{a}, \mathbf{b}(5 \mathrm{mmol})$ and sodium nitrite $(0.5 \mathrm{~g}, 7 \mathrm{mmol})$ was stirred in glacial acetic acid for $1 \mathrm{~h}$, then stirring was continued at room temperature for another $1 \mathrm{~h}$. The obtained solid was collected by filtration, washed with cold water and air-dried to furnish 6-(4-methoxyphenyl/3,4-dimethoxyphenyl)-2-methylnicotinoyl azide 5a,b, which used in the next reaction without further purification. Then, the appropriate nicotinoyl azide $\mathbf{5} \mathbf{a}, \mathbf{b}$ was heated under reflux in dry xylene for $1 \mathrm{~h}$ before addition of anilines $7 \mathbf{a}-\mathbf{g}$. The reaction mixture was refluxed for $3 \mathrm{~h}$ then allowed to cool to room temperature. The formed precipitate was filtered off, washed with cold acetone, dried and recrystallized from dioxane to furnish the target pyridines $\mathbf{8 a}-\mathbf{n}$.

1-(6-(4-Methoxyphenyl)-2-methylpyridin-3-yl)-3-phenylurea (8a). White crystals (yield 72\%), m.p. 205-207 ${ }^{\circ}$; IR (KBr, $\left.v \mathrm{~cm}^{-1}\right) 3387(\mathrm{NH}), 1653(\mathrm{C}=\mathrm{O}) ;{ }^{1} \mathrm{H}-\mathrm{NMR}\left(\mathrm{CDCl}_{3}-d\right) \delta$ ppm: $2.51\left(\mathrm{~s}, 3 \mathrm{H},-\mathrm{CH}_{3}\right)$, $3.86\left(\mathrm{~s}, 3 \mathrm{H},-\mathrm{OCH}_{3}\right), 6.29\left(\mathrm{~s}, 1 \mathrm{H}, \mathrm{NH}, \mathrm{D}_{2} \mathrm{O}\right.$ exchangeable); $6.40\left(\mathrm{~s}, 1 \mathrm{H}, \mathrm{NH}, \mathrm{D}_{2} \mathrm{O}\right.$ exchangeable), $6.98(\mathrm{~d}, 2 \mathrm{H}, J=8.8 \mathrm{~Hz}, \mathrm{Ar}-\mathrm{H}), 7.16(\mathrm{~m}, 1 \mathrm{H}, \mathrm{Ar}-\mathrm{H}), 7.38(\mathrm{~m}, 4 \mathrm{H}, \mathrm{Ar}-\mathrm{H}), 7.55(\mathrm{~d}, 1 \mathrm{H}, J=8.4 \mathrm{~Hz}$, Ar-H), 7.93 (d, 2H, $J=8.8 \mathrm{~Hz}, \mathrm{Ar}-\mathrm{H}), 8.05(\mathrm{~d}, 1 \mathrm{H}, J=8.4 \mathrm{~Hz}, \mathrm{Ar}-\mathrm{H}) ;{ }^{13} \mathrm{C}-\mathrm{NMR}\left(\mathrm{DMSO}-d_{6}\right) \delta \mathrm{ppm}$ : $21.38\left(\mathrm{CH}_{3}\right), 55.18\left(\mathrm{OCH}_{3}\right), 113.99,116.96,118.10,121.96,127.24,128.25,128.88,131.17,132.13,139.59$, 147.36, 149.00, 152.62 ( $\underline{\mathrm{C}}=\mathrm{O}), 159.51\left(=\mathrm{C}-\mathrm{O}-\mathrm{CH}_{3}\right)$; HRMS (ESI) $\mathrm{m} / z$ calcd for $[\mathrm{M}+\mathrm{H}]^{+}\left(\mathrm{C}_{20} \mathrm{H}_{20} \mathrm{~N}_{3} \mathrm{O}_{2}\right)$ : 334.15500, found: 334.15499; Anal. Calcd. for $\mathrm{C}_{20} \mathrm{H}_{20} \mathrm{~N}_{3} \mathrm{O}_{2}$ (333.39): C, 72.05; H, 5.74; N, 12.60; found C, 72.04; H, 5.71; N, 12.61 .

1-(6-(4-Methoxyphenyl)-2-methylpyridin-3-yl)-3-(3-(trifluoromethyl)phenyl) Urea (8b). White crystals (yield 75\%), m.p. $\quad 189-191{ }^{\circ} \mathrm{C}$; IR (KBr, $\left.v \mathrm{~cm}^{-1}\right) 3405(\mathrm{NH}), 1716(\mathrm{C}=\mathrm{O}) ;{ }^{1} \mathrm{H}-\mathrm{NMR}\left(\mathrm{CDCl}_{3}-d\right)$ $\delta$ ppm: $2.60\left(\mathrm{~s}, 3 \mathrm{H},-\mathrm{CH}_{3}\right), 3.87\left(\mathrm{~s}, 3 \mathrm{H},-\mathrm{OCH}_{3}\right), 6.28\left(\mathrm{~s}, 1 \mathrm{H}, \mathrm{NH}, \mathrm{D}_{2} \mathrm{O}\right.$ exchangeable); $6.62\left(\mathrm{~s}, 1 \mathrm{H}, \mathrm{NH}, \mathrm{D}_{2} \mathrm{O}\right.$ exchangeable), $6.99(\mathrm{~d}, 2 \mathrm{H}, J=8.8 \mathrm{~Hz}, \mathrm{Ar}-\mathrm{H}), 7.35(\mathrm{~d}, 1 \mathrm{H}, J=7.7 \mathrm{~Hz}, \mathrm{Ar}-\mathrm{H})$, $7.44(\mathrm{t}, 1 \mathrm{H}, J=8 \mathrm{~Hz}, \mathrm{Ar}-\mathrm{H}), 7.58(\mathrm{~d}, 1 \mathrm{H}, J=8.4 \mathrm{~Hz}, \mathrm{Ar}-\mathrm{H}), 7.61$ (d, 1H, J = 8 Hz, Ar-H), 7.68 (s, $1 \mathrm{H}$, Ar-H), 7.89-7.99 (m, 3H, Ar-H); ${ }^{13} \mathrm{C}-\mathrm{NMR}\left(\mathrm{DMSO}-d_{6}\right) \delta$ ppm: $21.34\left(\mathrm{CH}_{3}\right), 55.18\left(\mathrm{OCH}_{3}\right), 114.00,116.97$, $118.20,121.70,123.12,125.28,127.32,128.97,129.45,129.70,130.03,131.09,131.70,140.49,148.03,149.52$, $152.67(\underline{\mathrm{C}}=\mathrm{O}), 159.59$ (=C-O-CH$)$; HRMS (ESI) $m / z$ calcd for $[\mathrm{M}+\mathrm{H}]^{+}\left(\mathrm{C}_{21} \mathrm{H}_{19} \mathrm{~N}_{3} \mathrm{O}_{2} \mathrm{~F}_{3}\right): 402.14239$, found: 302.14220; Anal. Calcd. for $\mathrm{C}_{21} \mathrm{H}_{19} \mathrm{~N}_{3} \mathrm{O}_{2} \mathrm{~F}_{3}$ (401.39): C, 62.84; H, 4.52; N, 10.47; found C, 62.81; $\mathrm{H}, 4.52 ; \mathrm{N}, 10.44$.

1-(3-Chlorophenyl)-3-(6-(4-methoxyphenyl)-2-methylpyridin-3-yl) Urea (8c). White crystals (yield 81\%), m.p. $212-214{ }^{\circ} \mathrm{C}$; IR (KBr, $\left.v \mathrm{~cm}^{-1}\right) 3395(\mathrm{NH}), 1733(\mathrm{C}=\mathrm{O}) ;{ }^{1} \mathrm{H}-\mathrm{NMR}\left(\mathrm{MeOD}-d_{4}\right) \delta \mathrm{ppm}: 2.50(\mathrm{~s}, 3 \mathrm{H}$, $\left.\mathrm{CH}_{3}\right), 3.78\left(\mathrm{~s}, 3 \mathrm{H},-\mathrm{OCH}_{3}\right), 6.28\left(\mathrm{~s}, 1 \mathrm{H}, \mathrm{NH}, \mathrm{D}_{2} \mathrm{O}\right.$ exchangeable); $6.62\left(\mathrm{~s}, 1 \mathrm{H}, \mathrm{NH}, \mathrm{D}_{2} \mathrm{O}\right.$ exchangeable), 6.89-6.99 (m, 3H, Ar-H), 7.15-7.25 (m, 2H, Ar-H), 7.52 (dd, 2H, J = 2.1 Hz, J = 8.4 Hz, Ar-H), $7.80(\mathrm{~d}, 2 \mathrm{H}, J=8.8 \mathrm{~Hz}, \mathrm{Ar}-\mathrm{H}), 8.09(\mathrm{~d}, 1 \mathrm{H}, J=8.4 \mathrm{~Hz}, \mathrm{Ar}-\mathrm{H}) ;{ }^{13} \mathrm{C}-\mathrm{NMR}\left(\mathrm{DMSO}-d_{6}\right) \delta \mathrm{ppm}: 21.35\left(\mathrm{CH}_{3}\right)$, $55.18\left(\mathrm{OCH}_{3}\right), 114.00,116.55,116.97,117.47,121.57,127.30,128.76,130.49,131.10,131.77,133.26,141.15$, $147.85,149.40,152.52$ ( $\underline{\mathrm{C}}=\mathrm{O}), 159.57\left(=\mathrm{C}-\mathrm{O}-\mathrm{CH}_{3}\right)$; HRMS (ESI) $m / z$ calcd for $[\mathrm{M}+\mathrm{H}]^{+}\left(\mathrm{C}_{20} \mathrm{H}_{19} \mathrm{~N}_{3} \mathrm{O}_{2} \mathrm{Cl}\right)$ : 368.11603, found: 368.11605; Anal. Calcd. for $\mathrm{C}_{20} \mathrm{H}_{19} \mathrm{~N}_{3} \mathrm{O}_{2} \mathrm{Cl}$ (367.83): C, 65.31; H, 4.93; N, 11.42; found C, 65.34; H, 4.90; N, 11.41 .

1-(4-Chlorophenyl)-3-(6-(4-methoxyphenyl)-2-methylpyridin-3-yl) Urea (8d). White crystals (yield 83\%), m.p. $231-232{ }^{\circ} \mathrm{C}$; IR (KBr, $\left.v \mathrm{~cm}^{-1}\right) 3387(\mathrm{NH}), 1733(\mathrm{C}=\mathrm{O}) ;{ }^{1} \mathrm{H}-\mathrm{NMR}\left(\mathrm{CDCl}_{3}-d\right) \delta \mathrm{ppm}: 2.57(\mathrm{~s}, 3 \mathrm{H}$, $\left.-\mathrm{CH}_{3}\right), 3.87\left(\mathrm{~s}, 3 \mathrm{H},-\mathrm{OCH}_{3}\right), 6.18\left(\mathrm{~s}, 1 \mathrm{H}, \mathrm{NH}, \mathrm{D}_{2} \mathrm{O}\right.$ exchangeable); $6.37\left(\mathrm{~s}, 1 \mathrm{H}, \mathrm{NH}, \mathrm{D}_{2} \mathrm{O}\right.$ exchangeable), $6.99(\mathrm{~d}, 2 \mathrm{H}, \mathrm{J}=8.8 \mathrm{~Hz}, \mathrm{Ar}-\mathrm{H}), 7.27-7.38$ (m, 3H, Ar-H), 7.52-7.60 (m, 2H, Ar-H), 7.91-8.00 (m, 3H, Ar-H); ${ }^{13} \mathrm{C}-\mathrm{NMR}\left(\mathrm{DMSO}-d_{6}\right) \delta$ ppm: $21.36\left(\mathrm{CH}_{3}\right), 55.18\left(\mathrm{OCH}_{3}\right), 113.99,116.97,119.63,125.44,127.27$, $128.71,131.12,131.91,138.61,147.68,149.24,152.55$ ( $\underline{C}=\mathrm{O}), 159.54$ (=C-O-CH$)$; HRMS (ESI) $\mathrm{m} / z$ calcd for $[\mathrm{M}+\mathrm{H}]^{+}\left(\mathrm{C}_{20} \mathrm{H}_{19} \mathrm{~N}_{3} \mathrm{O}_{2} \mathrm{Cl}\right)$ : 368.11603, found: 368.11603; Anal. Calcd. for $\mathrm{C}_{20} \mathrm{H}_{19} \mathrm{~N}_{3} \mathrm{O}_{2} \mathrm{Cl}$ (367.83): C, 65.31; H, 4.93; N, 11.42; found C, 65.30; H, 4.92; N, 11.40 .

1-(4-Chloro-3-(trifluoromethyl)phenyl)-3-(6-(4-methoxyphenyl)-2-methylpyridin-3-yl)urea (8e). White crystals (yield 74\%), m.p. $195-197{ }^{\circ} \mathrm{C}$; IR (KBr, $\left.v \mathrm{~cm}^{-1}\right) 3394(\mathrm{NH}), 1733(\mathrm{C}=\mathrm{O}) ;{ }^{1} \mathrm{H}-\mathrm{NMR}\left(\mathrm{CDCl}_{3}-\mathrm{d}\right) \delta$ ppm: $2.61\left(\mathrm{~s}, 3 \mathrm{H},-\mathrm{CH}_{3}\right), 3.87\left(\mathrm{~s}, 3 \mathrm{H},-\mathrm{OCH}_{3}\right), 6.25\left(\mathrm{~s}, 1 \mathrm{H}, \mathrm{NH}, \mathrm{D}_{2} \mathrm{O}\right.$ exchangeable); $6.60(\mathrm{~s}, 1 \mathrm{H}$, 
$\mathrm{NH}, \mathrm{D}_{2} \mathrm{O}$ exchangeable), $6.99(\mathrm{~d}, 2 \mathrm{H}, J=8.5 \mathrm{~Hz}, \mathrm{Ar}-\mathrm{H}), 7.44(\mathrm{~d}, 1 \mathrm{H}, J=8.7 \mathrm{~Hz}, \mathrm{Ar}-\mathrm{H}), 7.57-7.71(\mathrm{~m}, 3 \mathrm{H}$, Ar-H), 7.90-7.95 (m, 3H, Ar-H); ${ }^{13} \mathrm{C}-\mathrm{NMR}\left(\mathrm{DMSO}-d_{6}\right) \delta \mathrm{ppm}: 21.32\left(\mathrm{CH}_{3}\right), 55.18\left(\mathrm{OCH}_{3}\right), 114.01,116.60$, 116.98, 121.72, 122.37, 122.92, 123.86, 126.88, 127.35, 129.34, 131.05, 131.50, 132.10, 139.26, 148.37, 149.77, $152.59(\underline{\mathrm{C}}=\mathrm{O}), 159.62\left(=\underline{\mathrm{C}}-\mathrm{O}-\mathrm{CH}_{3}\right)$; HRMS (ESI) $\mathrm{m} / z$ calcd for $[\mathrm{M}+\mathrm{H}]^{+}\left(\mathrm{C}_{21} \mathrm{H}_{18} \mathrm{~N}_{3} \mathrm{O}_{2} \mathrm{ClF}_{3}\right): 436.10342$, found: 436.10332; Anal. Calcd. for $\mathrm{C}_{21} \mathrm{H}_{18} \mathrm{~N}_{3} \mathrm{O}_{2} \mathrm{ClF}_{3}$ (435.83): C, 57.87; $\mathrm{H}, 3.93 ; \mathrm{N}, 9.64$; found $\mathrm{C}, 57.82$; $\mathrm{H}, 3.90 ; \mathrm{N}, 9.61$.

1-(3-Methoxyphenyl)-3-(6-(4-methoxyphenyl)-2-methylpyridin-3-yl) Urea (8f). White crystals (yield 83\%), m.p. 227-230 ${ }^{\circ} \mathrm{C}$; IR (KBr, $\left.v \mathrm{~cm}^{-1}\right) 3395(\mathrm{NH}), 1733(\mathrm{C}=\mathrm{O}) ;{ }^{1} \mathrm{H}-\mathrm{NMR}\left(\mathrm{CDCl}_{3}-d\right) \delta$ ppm: $2.49(\mathrm{~s}, 3 \mathrm{H}$, $\left.\mathrm{CH}_{3}\right), 3.81\left(\mathrm{~s}, 3 \mathrm{H},-\mathrm{OCH}_{3}\right), 3.83\left(\mathrm{~s}, 3 \mathrm{H},-\mathrm{OCH}_{3}\right), 6.30\left(\mathrm{~s}, 1 \mathrm{H}, \mathrm{NH}, \mathrm{D}_{2} \mathrm{O}\right.$ exchangeable), $6.60(\mathrm{~s}, 1 \mathrm{H}, \mathrm{NH}$, $\mathrm{D}_{2} \mathrm{O}$ exchangeable), 6.91-7.00 (m, 3H, Ar-H), 7.15-7.27 (m, 2H, Ar-H), $7.53(\mathrm{dd}, 2 \mathrm{H}, J=2.1 \mathrm{~Hz}, J=8.4$ $\mathrm{Hz}, \mathrm{Ar}-\mathrm{H}), 7.80(\mathrm{~d}, 2 \mathrm{H}, J=8.8 \mathrm{~Hz}, \mathrm{Ar}-\mathrm{H}), 8.09(\mathrm{~d}, 1 \mathrm{H}, J=8.4 \mathrm{~Hz}, \mathrm{Ar}-\mathrm{H}) ;{ }^{13} \mathrm{C}-\mathrm{NMR}$ (DMSO- $\left.d_{6}\right) \delta \mathrm{ppm}$ : $21.32\left(\mathrm{CH}_{3}\right), 55.18\left(2 \mathrm{OCH}_{3}\right), 114.01,116.60,116.98,121.72,122.37,122.92,123.86,126.88,127.35,129.34$, 131.05, 131.50, 132.10, 139.26, 148.37, 149.77, 152.59 ( $\underline{\mathrm{C}}=\mathrm{O}), 159.62$ (=-ㅡ-O $\left.\mathrm{CH}_{3}\right) ; \mathrm{HRMS}$ (ESI) $\mathrm{m} / \mathrm{z}$ calcd for $[\mathrm{M}+\mathrm{H}]^{+}\left(\mathrm{C}_{21} \mathrm{H}_{22} \mathrm{~N}_{3} \mathrm{O}_{3}\right): 364.16557$, found: 364.16565 .

1-(4-Methoxyphenyl)-3-(6-(4-methoxyphenyl)-2-methylpyridin-3-yl) Urea (8g). White crystals (yield 80\%), m.p. 241-242 ${ }^{\circ} \mathrm{C}$; IR (KBr, $\left.v \mathrm{~cm}^{-1}\right) 3387(\mathrm{NH}), 1733(\mathrm{C}=\mathrm{O}) ;{ }^{1} \mathrm{H}-\mathrm{NMR}\left(\mathrm{CDCl}_{3}-d\right) \delta \mathrm{ppm}: 2.42(\mathrm{~s}, 3 \mathrm{H}$, $\left.-\mathrm{CH}_{3}\right), 3.83\left(\mathrm{~s}, 3 \mathrm{H},-\mathrm{OCH}_{3}\right), 3.85\left(\mathrm{~s}, 3 \mathrm{H},-\mathrm{OCH}_{3}\right), 6.22\left(\mathrm{~s}, 1 \mathrm{H}, \mathrm{NH}, \mathrm{D}_{2} \mathrm{O}\right.$ exchangeable), $6.60(\mathrm{~s}, 1 \mathrm{H}$, $\mathrm{NH}, \mathrm{D}_{2} \mathrm{O}$ exchangeable), 6.91-7.00 (m, 4H, Ar-H), $7.53(\mathrm{~d}, 2 \mathrm{H}, J=8.4 \mathrm{~Hz}, \mathrm{Ar}-\mathrm{H}), 7.91(\mathrm{~d}, 2 \mathrm{H}, J=8.8$ $\mathrm{Hz}, \mathrm{Ar}-\mathrm{H}), 8.13(\mathrm{~d}, 2 \mathrm{H}, J=8.4 \mathrm{~Hz}, \mathrm{Ar}-\mathrm{H}) ;{ }^{13} \mathrm{C}-\mathrm{NMR}$ (DMSO-d $\left.d_{6}\right) \delta \mathrm{ppm}: 21.37\left(\mathrm{CH}_{3}\right), 55.17\left(2 \mathrm{OCH}_{3}\right)$, 159.47 (으), 113.97, 114.07, 116.94, 119.87, 127.20, 128.02, 131.20, 132.33, 132.61, 147.15, 148.77, 152.77, $154.51(\underline{\mathrm{C}}=\mathrm{O}), 159.47\left(=\underline{\mathrm{C}}-\mathrm{O}-\mathrm{CH}_{3}\right)$; HRMS (ESI) $\mathrm{m} / z$ calcd for $[\mathrm{M}+\mathrm{H}]^{+}\left(\mathrm{C}_{21} \mathrm{H}_{22} \mathrm{~N}_{3} \mathrm{O}_{3}\right): 364.16557$, found: 364.16597; Anal. Calcd. for $\mathrm{C}_{21} \mathrm{H}_{22} \mathrm{~N}_{3} \mathrm{O}_{3}$ (363.42): $\mathrm{C}, 69.41 ; \mathrm{H}, 5.82 ; \mathrm{N}, 11.56$; found $\mathrm{C}, 69.44 ; \mathrm{H}$, $5.80 ; \mathrm{N}, 11.56$.

1-(6-(3, 4-Dimethoxyphenyl) -2-methylpyridin-3-yl) -3-phenylurea (8h). White crystals (yield 77\%), m.p. $238-239{ }^{\circ} \mathrm{C}$; IR $\left(\mathrm{KBr}, v \mathrm{~cm}^{-1}\right) 3398(\mathrm{NH}), 1733(\mathrm{C}=\mathrm{O}) ;{ }^{1} \mathrm{H}-\mathrm{NMR}\left(\mathrm{CDCl}_{3}-d\right) \delta \mathrm{ppm}: 2.42(\mathrm{~s}, 3 \mathrm{H}$, $\left.\mathrm{CH}_{3}\right), 3.83\left(\mathrm{~s}, 3 \mathrm{H},-\mathrm{OCH}_{3}\right), 3.85\left(\mathrm{~s}, 3 \mathrm{H},-\mathrm{OCH}_{3}\right), 6.32\left(\mathrm{~s}, 1 \mathrm{H}, \mathrm{NH}, \mathrm{D}_{2} \mathrm{O}\right.$ exchangeable); $6.44(\mathrm{~s}, 1 \mathrm{H}, \mathrm{NH}$, $\mathrm{D}_{2} \mathrm{O}$ exchangeable), $6.94(\mathrm{~d}, 1 \mathrm{H}, J=8.6 \mathrm{~Hz}, \mathrm{Ar}-\mathrm{H}), 7.39-7.42(\mathrm{~m}, 5 \mathrm{H}, \mathrm{Ar}-\mathrm{H}), 7.51-7.62(\mathrm{~m}, 3 \mathrm{H}, \mathrm{Ar}-\mathrm{H})$, $8.08(\mathrm{~d}, 1 \mathrm{H}, J=8.8 \mathrm{~Hz}, \mathrm{Ar}-\mathrm{H}) ;{ }^{13} \mathrm{C}-\mathrm{NMR}\left(\mathrm{DMSO}-d_{6}\right) \delta$ ppm: $21.42\left(\mathrm{CH}_{3}\right), 55.52\left(2 \mathrm{OCH}_{3}\right), 109.48$, $111.73,117.20,118.12,118.50,121.96,128.13,128.88,131.43,132.20,139.59,147.25,148.83,149.00,149.19$, $152.63(\mathrm{C}=\mathrm{O})$; HRMS (ESI) $m / z$ calcd for $[\mathrm{M}+\mathrm{H}]^{+}\left(\mathrm{C}_{21} \mathrm{H}_{22} \mathrm{~N}_{3} \mathrm{O}_{3}\right): 364.16557$, found: 364.16528; Anal. Calcd. for $\mathrm{C}_{21} \mathrm{H}_{22} \mathrm{~N}_{3} \mathrm{O}_{3}$ (363.42): $\mathrm{C}, 69.41 ; \mathrm{H}, 5.82 ; \mathrm{N}, 11.56$; found $\mathrm{C}, 69.40 ; \mathrm{H}, 5.80 ; \mathrm{N}, 11.52$.

1-(6-(3,4-Dimethoxyphenyl)-2-methylpyridin-3-yl)-3-(3-(trifluoromethyl)phenyl) Urea (8i). White crystals (yield 80\%), m.p. $235-237{ }^{\circ} \mathrm{C}$; IR ( $\left.\mathrm{KBr}, v \mathrm{~cm}^{-1}\right) 3396(\mathrm{NH}), 1733(\mathrm{C}=\mathrm{O}) ;{ }^{1} \mathrm{H}-\mathrm{NMR}\left(\mathrm{CDCl}_{3}-d\right) \delta$ ppm: $2.55\left(\mathrm{~s}, 3 \mathrm{H}, \mathrm{CH}_{3}\right), 3.93\left(\mathrm{~s}, 3 \mathrm{H},-\mathrm{OCH}_{3}\right), 3.98\left(\mathrm{~s}, 3 \mathrm{H},-\mathrm{OCH}_{3}\right), 6.56\left(\mathrm{~s}, 1 \mathrm{H}, \mathrm{NH}, \mathrm{D}_{2} \mathrm{O}\right.$ exchangeable), $6.93(\mathrm{~d}, 1 \mathrm{H}, J=8.6 \mathrm{~Hz}, \operatorname{Ar}-\mathrm{H}), 7.00(\mathrm{~s}, 1 \mathrm{H}, \mathrm{Ar}-\mathrm{H}), 7.33(\mathrm{~d}, 1 \mathrm{H}, J=7.6 \mathrm{~Hz}, \mathrm{Ar}-\mathrm{H}), 7.40(\mathrm{t}, 1 \mathrm{H}$, $J=7.6 \mathrm{~Hz}, \mathrm{Ar}-\mathrm{H}), 7.47(\mathrm{dd}, 1 \mathrm{H}, J=2.0 \mathrm{~Hz}, J=8.5 \mathrm{~Hz}, \mathrm{Ar}-\mathrm{H}), 7.52-7.62(\mathrm{~m}, 2 \mathrm{H}, \mathrm{Ar}-\mathrm{H}), 7.65(\mathrm{~s}, 1 \mathrm{H}$, $\mathrm{Ar}-\mathrm{H}), 7.97(\mathrm{~d}, 1 \mathrm{H}, J=8.6 \mathrm{~Hz}, \mathrm{Ar}-\mathrm{H}) ;{ }^{13} \mathrm{C}-\mathrm{NMR}\left(\mathrm{DMSO}-d_{6}\right) \delta \mathrm{ppm}: 21.38\left(\mathrm{CH}_{3}\right), 55.53\left(2 \mathrm{OC}_{3}\right), 109.53$, 111.73, 114.02, 117.21, 118.60, 121.72, 123.12, 125.28, 128.82, 129.70, 130.04, 131.33, 131.77, 140.47, 147.89, $148.84,149.28,149.52,152.65(\mathrm{C}=\mathrm{O})$; HRMS (ESI) $m / z$ calcd for $[\mathrm{M}+\mathrm{H}]^{+}\left(\mathrm{C}_{22} \mathrm{H}_{21} \mathrm{~N}_{3} \mathrm{O}_{3} \mathrm{~F}_{3}\right): 432.15295$, found: 432.15283; Anal. Calcd. for $\mathrm{C}_{22} \mathrm{H}_{21} \mathrm{~N}_{3} \mathrm{O}_{3} \mathrm{~F}_{3}$ (431.42): $\mathrm{C}, 61.25 ; \mathrm{H}, 4.67 ; \mathrm{N}, 9.74$; found $\mathrm{C}, 61.22 ; \mathrm{H}$, $4.65 ; \mathrm{N}, 9.71$.

1-(3-Chlorophenyl)-3-(6-(3,4-dimethoxyphenyl)-2-methylpyridin-3-yl) Urea (8j). White crystals (yield 76\%), m.p. 249-250 ${ }^{\circ} \mathrm{C}$; IR $\left(\mathrm{KBr}, v \mathrm{~cm}^{-1}\right) 3373(\mathrm{NH}), 1733(\mathrm{C}=\mathrm{O}) ;{ }^{1} \mathrm{H}-\mathrm{NMR}\left(\mathrm{CDCl}_{3}-d\right) \delta \mathrm{ppm}: 2.57(\mathrm{~s}, 3 \mathrm{H}$, $\left.-\mathrm{CH}_{3}\right), 3.94\left(\mathrm{~s}, 3 \mathrm{H},-\mathrm{OCH}_{3}\right), 3.99\left(\mathrm{~s}, 3 \mathrm{H},-\mathrm{OCH}_{3}\right), 6.37\left(\mathrm{~s}, 1 \mathrm{H}, \mathrm{NH}, \mathrm{D}_{2} \mathrm{O}\right.$ exchangeable), $6.62(\mathrm{~s}, 1 \mathrm{H}, \mathrm{NH}$, $\mathrm{D}_{2} \mathrm{O}$ exchangeable), $6.94(\mathrm{~d}, 1 \mathrm{H}, J=8.4 \mathrm{~Hz}, \mathrm{Ar}-\mathrm{H}), 7.05-7.13(\mathrm{~m}, 1 \mathrm{H}, \mathrm{Ar}-\mathrm{H}), 7.45-7.53(\mathrm{~m}, 4 \mathrm{H}, \mathrm{Ar}-\mathrm{H})$, $7.56(\mathrm{~d}, 1 \mathrm{H}, J=8.4 \mathrm{~Hz}, \mathrm{Ar}-\mathrm{H}), 7.63(\mathrm{~s}, 1 \mathrm{H}, \mathrm{Ar}-\mathrm{H}), 7.99(\mathrm{~d}, 1 \mathrm{H}, J=8.4 \mathrm{~Hz}, \mathrm{Ar}-\mathrm{H}) ;{ }^{13} \mathrm{C}-\mathrm{NMR}\left(\mathrm{DMSO}-d_{6}\right) \delta$ ppm: $21.41\left(\underline{\mathrm{CH}}_{3}\right), 55.54\left(2 \mathrm{O}_{\mathrm{CH}}\right), 109.52,111.74,116.57,117.22,117.48,118.58,121.59,128.63,130.51$, $131.35,131.85,133.27,141.16,147.73,148.84,149.26,149.41,152.53$ (C=O); HRMS (ESI) $m / z$ calcd for 
$[\mathrm{M}+\mathrm{H}]^{+}\left(\mathrm{C}_{21} \mathrm{H}_{21} \mathrm{~N}_{3} \mathrm{O}_{3} \mathrm{Cl}\right): 398.12660$, found: 398.12642; Anal. Calcd. for $\mathrm{C}_{21} \mathrm{H}_{21} \mathrm{~N}_{3} \mathrm{O}_{3} \mathrm{Cl}$ (397.86): $\mathrm{C}$, 63.40; H, 5.07; N, 10.56; found $\mathrm{C}, 63.41 ; \mathrm{H}, 5.02 ; \mathrm{N}, 10.54$.

1-(4-Chlorophenyl)-3-(6-(3,4-dimethoxyphenyl)-2-methylpyridin-3-yl) Urea (8k). White crystals (yield 81\%), m.p. 266-267 ${ }^{\circ} \mathrm{C}$; IR $\left(\mathrm{KBr}, v \mathrm{~cm}^{-1}\right) 3388(\mathrm{NH}), 1733(\mathrm{C}=\mathrm{O}) ;{ }^{1} \mathrm{H}-\mathrm{NMR}\left(\mathrm{CDCl}_{3}-d\right) \delta \mathrm{ppm}: 2.57(\mathrm{~s}, 3 \mathrm{H}$, $\left.\mathrm{CH}_{3}\right), 3.94\left(\mathrm{~s}, 3 \mathrm{H},-\mathrm{OCH}_{3}\right), 4.00\left(\mathrm{~s}, 3 \mathrm{H},-\mathrm{OCH}_{3}\right), 6.22\left(\mathrm{~s}, 1 \mathrm{H}, \mathrm{NH}, \mathrm{D}_{2} \mathrm{O}\right.$ exchangeable), $6.41(\mathrm{~s}, 1 \mathrm{H}, \mathrm{NH}$, $\mathrm{D}_{2} \mathrm{O}$ exchangeable), $6.95(\mathrm{~d}, 1 \mathrm{H}, J=8.5 \mathrm{~Hz}, \mathrm{Ar}-\mathrm{H}), 7.30-7.35(\mathrm{~m}, 4 \mathrm{H}, \mathrm{Ar}-\mathrm{H}), 7.51(\mathrm{~d}, 1 \mathrm{H}, J=8.8 \mathrm{~Hz}$, Ar-H), 7.54-7.65 (m, 2H, Ar-H), 7.99 (d, $1 \mathrm{H}, J=8.5 \mathrm{~Hz}, \mathrm{Ar}-\mathrm{H}) ;{ }^{13} \mathrm{C}-\mathrm{NMR}\left(\mathrm{DMSO}-d_{6}\right) \delta$ ppm: $21.41\left(\mathrm{CH}_{3}\right)$, $55.51\left(2 \mathrm{OCH}_{3}\right), 109.50,111.73,117.20,118.54,119.64,125.43,128.46,128.70,131.38,131.99,138.63$, 147.59, 148.83, 149.25, 152.56 (C=O); HRMS (ESI) $m / z$ calcd for $[\mathrm{M}+\mathrm{H}]^{+}\left(\mathrm{C}_{21} \mathrm{H}_{21} \mathrm{~N}_{3} \mathrm{O}_{3} \mathrm{Cl}\right): 398.12660$, found: 398.12673; Anal. Calcd. for $\mathrm{C}_{21} \mathrm{H}_{21} \mathrm{~N}_{3} \mathrm{O}_{3} \mathrm{Cl}$ (397.86): $\mathrm{C}, 63.40 ; \mathrm{H}, 5.07 ; \mathrm{N}, 10.56$; found $\mathrm{C}, 63.40$; $\mathrm{H}, 5.04 ; \mathrm{N}, 10.52$.

1-(4-Chloro-4-(trifluoromethyl)cyclohexa-2,5-dien-1-yl)-3-(6-(3,4-dimethoxyphenyl)-2-methylpyridin-3-yl)urea (81). White crystals (yield 79\%), m.p. 261-263 ${ }^{\circ} \mathrm{C}$; IR (KBr, $\left.v \mathrm{~cm}^{-1}\right) 3393(\mathrm{NH}), 1733(\mathrm{C}=\mathrm{O}) ;{ }^{1} \mathrm{H}-\mathrm{NMR}$ $\left(\mathrm{CDCl}_{3}-d\right) \delta$ ppm: $2.51\left(\mathrm{~s}, 3 \mathrm{H}, \mathrm{CH}_{3}\right), 3.92\left(\mathrm{~s}, 3 \mathrm{H},-\mathrm{OCH}_{3}\right), 3.96\left(\mathrm{~s}, 3 \mathrm{H},-\mathrm{OCH}_{3}\right), 6.22(\mathrm{~s}, 1 \mathrm{H}, \mathrm{NH}$, $\mathrm{D}_{2} \mathrm{O}$ exchangeable), $6.74\left(\mathrm{~s}, 1 \mathrm{H}, \mathrm{NH}, \mathrm{D}_{2} \mathrm{O}\right.$ exchangeable), $6.91(\mathrm{~d}, 1 \mathrm{H}, J=8.6 \mathrm{~Hz}, \mathrm{Ar}-\mathrm{H}), 7.28(\mathrm{~s}, 1 \mathrm{H}$, Ar-H), $7.35(\mathrm{~d}, 1 \mathrm{H}, J=9.0 \mathrm{~Hz}, \mathrm{Ar}-\mathrm{H}), 7.50(\mathrm{dd}, 2 \mathrm{H}, J=2.5, J=8.7 \mathrm{~Hz}, \mathrm{Ar}-\mathrm{H}), 7.58(\mathrm{~d}, 1 \mathrm{H}, J=2.0 \mathrm{~Hz}$, Ar-H), $7.65(\mathrm{~d}, 1 \mathrm{H}, J=2.4 \mathrm{~Hz}, \mathrm{Ar}-\mathrm{H}), 7.91(\mathrm{~d}, 1 \mathrm{H}, J=8.6 \mathrm{~Hz}, \mathrm{Ar}-\mathrm{H}) ;{ }^{13} \mathrm{C}-\mathrm{NMR}$ (DMSO- $d_{6}$ ) $\delta \mathrm{ppm}$ : $21.38\left(\mathrm{CH}_{3}\right), 55.53\left(2 \mathrm{OCH}_{3}\right), 109.56,111.73,117.22,118.65,121.74,122.34,122.93,129.30,131.32$, $131.62,132.10,139.34,148.33,148.84,149.32,149.78,152.65$ (C=O); HRMS (ESI) $\mathrm{m} / z$ calcd for $[\mathrm{M}+\mathrm{H}]^{+}$ $\left(\mathrm{C}_{22} \mathrm{H}_{20} \mathrm{~N}_{3} \mathrm{O}_{3} \mathrm{ClF}_{3}\right): 466.11398$, found: 466.11398; Anal. Calcd. for $\mathrm{C}_{22} \mathrm{H}_{20} \mathrm{~N}_{3} \mathrm{O}_{3} \mathrm{ClF}_{3}$ (465.86): $\mathrm{C}, 56.72$; $\mathrm{H}, 4.11 ; \mathrm{N}, 9.02$; found $\mathrm{C}, 59.51 ; \mathrm{H}, 4.61 ; \mathrm{N}, 9.20$

1-(6-(3,4-Dimethoxyphenyl)-2-methylpyridin-3-yl)-3-(3-methoxyphenyl) Urea (8m). White crystals (yield 80\%), m.p. $243-245{ }^{\circ} \mathrm{C}$; IR $\left(\mathrm{KBr}, v \mathrm{~cm}^{-1}\right) 3391(\mathrm{NH}), 1733(\mathrm{C}=\mathrm{O}) ;{ }^{1} \mathrm{H}-\mathrm{NMR}\left(\mathrm{CDCl}_{3}-d\right) \delta \mathrm{ppm}$ : $2.51\left(\mathrm{~s}, 3 \mathrm{H},-\mathrm{CH}_{3}\right), 3.80\left(\mathrm{~s}, 3 \mathrm{H},-\mathrm{OCH}_{3}\right), 3.92\left(\mathrm{~s}, 3 \mathrm{H},-\mathrm{OCH}_{3}\right), 3.98\left(\mathrm{~s}, 3 \mathrm{H},-\mathrm{OCH}_{3}\right), 6.22(\mathrm{~s}, 1 \mathrm{H}, \mathrm{NH}$, $\mathrm{D}_{2} \mathrm{O}$ exchangeable), $6.56\left(\mathrm{~s}, 1 \mathrm{H}, \mathrm{NH}, \mathrm{D}_{2} \mathrm{O}\right.$ exchangeable), 6.66-6.75 $(\mathrm{m}, 2 \mathrm{H}, \mathrm{Ar}-\mathrm{H}), 6.83-6.96(\mathrm{~m}, 2 \mathrm{H}$, Ar-H), $7.05(\mathrm{t}, 1 \mathrm{H}, J=2.3 \mathrm{~Hz}, \mathrm{Ar}-\mathrm{H}), 7.20-7.29(\mathrm{~m}, 2 \mathrm{H}, \mathrm{Ar}-\mathrm{H}), 7.60(\mathrm{~d}, 1 \mathrm{H}, J=2.0 \mathrm{~Hz}, \mathrm{Ar}-\mathrm{H})$, $8.06(\mathrm{~d}, 1 \mathrm{H}, J=8.5 \mathrm{~Hz}, \mathrm{Ar}-\mathrm{H}) ;{ }^{13} \mathrm{C}-\mathrm{NMR}\left(\mathrm{DMSO}-d_{6}\right) \delta \mathrm{ppm}: 21.40\left(\mathrm{C}_{3}\right), 54.93\left(\mathrm{OCH}_{3}\right), 55.53\left(2 \mathrm{OCH}_{3}\right)$, 103.87, 107.38, 109.49, 110.42, 111.73, 117.19, 118.51, 128.19, 129.65, 131.42, 132.13, 140.81, 147.28, 148.83, 149.05, 149.20, $152.55(\mathrm{C}=\mathrm{O})$; HRMS (ESI) $m / z$ calcd for $[\mathrm{M}+\mathrm{H}]^{+}\left(\mathrm{C}_{22} \mathrm{H}_{24} \mathrm{~N}_{3} \mathrm{O}_{4}\right)$ : 394.17613, found: 394.17608; Anal. Calcd. for $\mathrm{C}_{22} \mathrm{H}_{24} \mathrm{~N}_{3} \mathrm{O}_{4}$ (393.44): C, 67.16; $\mathrm{H}, 5.89 ; \mathrm{N}, 10.68$; found C, 67.12; $\mathrm{H}, 5.89$; N, 10.67 .

1-(6-(3,4-Dimethoxyphenyl)-2-methylpyridin-3-yl)-3-(4-methoxyphenyl) Urea (8n). White crystals (yield 80\%), m.p. $253-254{ }^{\circ} \mathrm{C}$; IR ( $\left.\mathrm{KBr}, v \mathrm{~cm}^{-1}\right) 3392(\mathrm{NH}), 1733(\mathrm{C}=\mathrm{O}) ;{ }^{1} \mathrm{H}-\mathrm{NMR}\left(\mathrm{CDCl}_{3}-d\right) \delta \mathrm{ppm}$ : $2.42\left(\mathrm{~s}, 3 \mathrm{H},-\mathrm{CH}_{3}\right), 3.83\left(\mathrm{~s}, 3 \mathrm{H},-\mathrm{OCH}_{3}\right), 3.92\left(\mathrm{~s}, 3 \mathrm{H},-\mathrm{OCH}_{3}\right), 3.98\left(\mathrm{~s}, 3 \mathrm{H},-\mathrm{OCH}_{3}\right), 6.27(\mathrm{~s}, 1 \mathrm{H}$, $\mathrm{NH}, \mathrm{D}_{2} \mathrm{O}$ exchangeable), $6.56\left(\mathrm{~s}, 1 \mathrm{H}, \mathrm{NH}, \mathrm{D}_{2} \mathrm{O}\right.$ exchangeable), $6.94(\mathrm{dd}, 3 \mathrm{H}, J=5.1 \mathrm{~Hz}, J=8.8$ $\mathrm{Hz}, \operatorname{Ar}-\mathrm{H}), 7.29(\mathrm{~d}, 2 \mathrm{H}, J=7.4 \mathrm{~Hz}, \mathrm{Ar}-\mathrm{H}), 7.47(\mathrm{~d}, 1 \mathrm{H}, J=7.9 \mathrm{~Hz}, \mathrm{Ar}-\mathrm{H}), 7.54(\mathrm{~d}, 1 \mathrm{H}, J=8.2 \mathrm{~Hz}$, Ar-H), 7.59 (s, 1H, Ar-H) 8.15 (d, $1 \mathrm{H}, J=8.0 \mathrm{~Hz}, \mathrm{Ar}-\mathrm{H}) ;{ }^{13} \mathrm{C}-\mathrm{NMR}$ (DMSO- $\left.d_{6}\right) \delta$ ppm: $21.43\left(\mathrm{CH}_{3}\right)$, $55.18\left(\mathrm{OCH}_{3}\right), 55.53\left(2 \mathrm{OCH}_{3}\right), 109.47,111.73,114.06,117.18,118.47,119.89,127.96,131.48,132.43$, 132.66, 147.09, 148.79, 148.83, 149.16, $152.81(\mathrm{C}=\mathrm{O}), 154.51$ (=C-O-CH 3 ); HRMS (ESI) $\mathrm{m} / z$ calcd for $[\mathrm{M}+\mathrm{H}]^{+}\left(\mathrm{C}_{22} \mathrm{H}_{24} \mathrm{~N}_{3} \mathrm{O}_{4}\right): 394.17613$, found: 394.17598; Anal. Calcd. for $\mathrm{C}_{22} \mathrm{H}_{24} \mathrm{~N}_{3} \mathrm{O}_{4}$ (393.44): C, 67.16; $\mathrm{H}, 5.89 ; \mathrm{N}, 10.68$; found $\mathrm{C}, 67.11 ; \mathrm{H}, 5.87 ; \mathrm{N}, 10.65$.

\subsection{Biological Evaluation}

\subsubsection{In Vitro Anti-Proliferative Activity towards Breast Cancer MCF7 Cell Line}

MCF-7 (human breast cancer cell line) and WI-38 (human lung fibroblast cell line), were obtained from American Type Culture Collection (Manassas, VA, USA). The cells were propagated in DMEM and supplemented with $10 \%$ heat-inactivated FBS (Hyclone), $10 \mu \mathrm{g} / \mathrm{mL}$ of insulin (Manufacturer, Sigma, St. Louis, MO, USA), and 1\% penicillin-streptomycin. MTT assay was utilized to examine the in vitro 
anti-proliferative activity of the newly prepared ureas following the reported procedures $[26,34,35]$. The 50\% inhibitory concentration ( $\mathrm{IC}_{50}$ ) was estimated, after 48 and $72 \mathrm{~h}$ for MCF-7 cells, from graphic plots of the dose response curve for each conc. using Graphpad Prism software (GraphPad Software, Inc., San Diego, CA, USA). The data presented are the mean of at least three separate experiments.

\subsubsection{In Vitro Cytotoxic Activity by NCI-USA}

The anticancer assays were performed in accordance with the protocol of the Drug Evaluation Branch, NCI, Bethesda [27-29]. A 48 h drug exposure protocol was used and sulforhodamine B (SRB) protein assay [30] was applied to estimate the cell viability and growth, as reported earlier [36,37].

\subsubsection{Measurement of Inhibitory Activity against VEGFR-2}

VEGFR-2 enzyme inhibition was measured for pyridines $\mathbf{8 b}$ and $\mathbf{8 e}$ using an anti-phosphotyrosine antibody with the Alpha Screen system (PerkinElmer, Waltham, MA, USA) according to the manufacturer's protocol and referring to reported instructions [19]. The concentration of the test compound causing 50\% inhibition ( $\mathrm{IC}_{50}$ ) was calculated from the concentration-inhibition response curve (triplicate determinations) and the data were compared with sorafenib as standard VEGFR-2 inhibitor.

\subsubsection{Physicochemical Properties and ADME Profiling}

Physicochemical properties and ADME profiling for the active pyridines $(\mathbf{8 a}, \mathbf{8 b}, \mathbf{8 e}, \mathbf{8 g}, \mathbf{8 i}, \mathbf{8 1}$ and 8n) were performed using Discovery Studio 2.5 (Accelrys, San Diego, CA, USA). The examined pyridines were drawn as a small library and prepared via prepare ligand protocol in order to find the suitable orientation in 3D. Then, the prepared library was filtered adopting the Lipinski and Veber rules protocols. ADME profiling was predicted for the designed library using ADME descriptors protocol.

\section{Conclusions}

In summary, herein we report the synthesis of a novel series of pyridine-ureas $\mathbf{8 a - n}$. All the prepared pyridines were evaluated for their anti-proliferative activity towards the breast cancer MCF-7cell line. Pyridines 8e and 8n were the most active members towards MCF-7 cells $\left(\mathrm{IC}_{50}=0.22\right.$ and $1.88 \mu \mathrm{M}$ after $48 \mathrm{~h}$ treatment; 0.11 and $0.80 \mu \mathrm{M}$ after $72 \mathrm{~h}$ treatment, respectively). Furthermore, eight selected pyridines $\mathbf{8 b}, \mathbf{8 d}, \mathbf{8 e}, \mathbf{8 i}, \mathbf{8 j}$ and $\mathbf{8 1 - n}$ were examined for their in vitro anticancer activity according to US-NCI protocol. Pyridines $\mathbf{8 b}$ and $\mathbf{8 e}$ emerged as the most effective anticancer agents in the NCI assay with mean inhibition $=43$ and $49 \%$, respectively. Both $8 \mathbf{b}$ and $8 \mathbf{e}$ exhibited

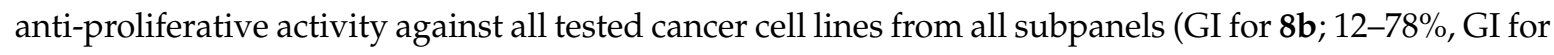
$\mathbf{8 e} ; \mathbf{1 5}-91 \%)$. Pyridines $\mathbf{8 b}$ and $\mathbf{8 e}$ were screened in vitro for their inhibitory activity against VEGFR-2. Both compounds inhibited VEGFR-2 at micromolar $\mathrm{IC}_{50}$ values $5.0 \pm 1.91$ and $3.93 \pm 0.73 \mu \mathrm{M}$, respectively. The most active pyridines were filtered according to the Lipinski and Veber rules and all of them passed these filters. Finally, several ADME descriptors were predicted for the active pyridines through a theoretical kinetic study. Further mechanistic studies are in progress in our laboratories and will be reported upon in the future

Supplementary Materials: The following are available online. Spectral data and NCI One Dose Mean Graph.

Author Contributions: H.A.A.-A. and W.M.E. conceived and designed the experiments; W.M.E., M.E.-N. and H.S.I. carried out the experiments; H.A. and H.S.I. analyzed and interpreted the data; H.A.A.-A., W.M.E. and M.E.-N. prepared the manuscript; All authors have read and approved the final manuscript.

Funding: "This research received no external funding"

Conflicts of Interest: The authors declare no conflict of interest. 


\section{References}

1. Adami, H.; Hunter, D.; Trichopoulos, D. Textbook of Cancer Epidemiology; Oxford University Press: New York, NY, USA, 2002; pp. 301-373.

2. International Agency for Research on Cancer. IGlobocan: Estimated Cancer Incidence, Mortality, and Prevalence Worldwide in 2012; IARC: Lyon, France, 2014.

3. Davari, A.S.; Abnous, K.; Mehri, S.; Ghandadi, M.; Hadizadeh, F. Synthesis and biological evaluation of novel pyridine derivatives as potential anticancer agents and phosphodiesterase-3 inhibitors. Bioorg. Chem. 2014, 57, 83-89. [CrossRef] [PubMed]

4. Lu, T.; Goh, A.W.; Yu, M.; Adams, J.; Lam, F.; Teo, T.; Li, P.; Noll, B.; Zhong, L.; Diab, S.; et al. Discovery of (E)-3-((Styrylsulfonyl)methyl)pyridine and (E)-2-((Styrylsulfonyl)methyl)pyridine Derivatives as Anticancer Agents: Synthesis, Structure-Activity Relationships, and Biological Activities. J. Med. Chem. 2014, 57, 2275-2291. [CrossRef] [PubMed]

5. Helal, M.H.; El-Awdan, S.A.; Salem, M.A.; Abd-Elaziz, T.A.; Moahamed, Y.A.; El-Sherif, A.A.; Mohamed, G.A.M. Synthesis, biological evaluation and molecular modeling of novel series of pyridine derivatives as anticancer, anti-inflammatory and analgesic agents. Spectrochim. Acta Part A 2015, 135, 764-773. [CrossRef] [PubMed]

6. Wilhelm, S.; Carter, C.; Lynch, M.; Lowinger, T.; Dumas, J.; Smith, R.A.; Schwartz, B.; Simantov, R.; Kelley, S. Discovery and development of sorafenib: A multikinase inhibitor for treating cancer. Nat. Rev. Drug Discov. 2006, 5, 835-844. [CrossRef] [PubMed]

7. DiGiulio, S. FDA Approves Stivarga for Advanced GIST. Oncol. Times 2013, 35, 12.

8. Cui, J.J.; Tran-Dubé, M.; Shen, H.; Nambu, M.; Kung, P.P.; Pairish, M.; Jia, L.; Meng, J.; Funk, L.; Botrous, I.; et al. Structure Based Drug Design of Crizotinib (PF-02341066), a Potent and Selective Dual Inhibitor of Mesenchymal-Epithelial Transition Factor (c-MET) Kinase and Anaplastic Lymphoma Kinase (ALK). J. Med. Chem. 2011, 54, 6342-6363. [CrossRef] [PubMed]

9. Choi, H.E.; Yoo, M.S.; Choi, J.H.; Lee, J.Y.; Kim, J.H.; Kim, J.H.; Lee, J.K.; Kim, G.I.; Park, Y.; Chi, Y.H.; et al. BRN-103, a novel nicotinamide derivative, inhibits VEGF-induced angiogenesis and proliferation in human umbilical vein endothelial cells. Bioorg. Med. Chem. Lett. 2011, 21, 6236-6241. [CrossRef] [PubMed]

10. Cao, Z.X.; Zheng, R.L.; Lin, H.J.; Luo, S.D.; Zhou, Y.; Xu, Y.Z.; Zeng, X.X.; Wang, Z.; Zhou, L.N.; Mao, Y.Q.; et al. SKLB610: A novel potential inhibitor of vascular endothelial growth factor receptor tyrosine kinases inhibits angiogenesis and tumor growth In Vivo. Cell. Physiol. Biochem. 2011, 27, 565-574. [CrossRef] [PubMed]

11. Li, H.Q.; Lv, P.C.; Yan, T.; Zhu, H.L. Urea derivatives as anticancer agents. Anti Cancer Agents Med. Chem. 2009, 9, 471-480. [CrossRef]

12. Tan, E.-H.; Goss, G.D.; Salgia, R.; Besse, B.; Gandara, D.R.; Hanna, N.H.; Yang, J.C.-H.; Thertulien, R.; Wertheim, M.; Mazieres, J. Phase 2 trial of Linifanib (ABT-869) in patients with advanced non-small cell lung cancer. J. Thorac. Oncol. 2011, 6, 1418-1425. [CrossRef] [PubMed]

13. Pacchiano, F.; Carta, F.; McDonald, P.C.; Lou, Y.; Vullo, D.; Scozzafava, A.; Dedhar, S.; Supuran, C.T. Ureido-substituted benzenesulfonamides potently inhibit carbonic anhydrase IX and show antimetastatic activity in a model of breast cancer metastasis. J. Med. Chem. 2011, 54, 1896-1902. [CrossRef] [PubMed]

14. Safety Study of SLC-0111 in Subjects with Advanced Solid Tumours. Available online: https://clinicaltrials. gov/ct2/show/NCT02215850 (accessed on 10 April 2018).

15. Lou, Y.; McDonald, P.C.; Oloumi, A.; Chia, S.; Ostlund, C.; Ahmadi, A.; Kyle, A.; auf dem Keller, U.; Leung, S.; Huntsman, D.; et al. Targeting tumor hypoxia: Suppression of breast tumor growth and metastasis by novel carbonic anhydrase IX inhibitors. Cancer Res. 2011, 71, 3364-3376. [CrossRef] [PubMed]

16. Supuran, C.T.; Winum, J.-Y. Designing carbonic anhydrase inhibitors for the treatment of breast cancer. Expert Opin. Drug Discov. 2015, 10, 591-597. [CrossRef] [PubMed]

17. Eldehna, W.M.; Altoukhy, A.; Mahrous, H.; Abdel-Aziz, H.A. Design, synthesis and QSAR study of certain isatin-pyridine hybrids as potential anti-proliferative agents. Eur. J. Med. Chem. 2015, 90, 684-694. [CrossRef] [PubMed]

18. Eldehna, W.M.; Fares, M.; Ibrahim, H.S.; Alsherbiny, M.A.; Aly, M.H.; Ghabbour, H.A.; Abdel-Aziz, H.A. Synthesis and cytotoxic activity of biphenylurea derivatives containing indolin-2-one moieties. Molecules 2016, 21, 762. [CrossRef] [PubMed] 
19. Eldehna, W.M.; Fares, M.; Ibrahim, H.S.; Aly, M.H.; Zada, S.; Ali, M.M.; Abou-Seri, S.M.; Abdel-Aziz, H.A.; Abou El Ella, D.A. Indoline ureas as potential anti-hepatocellular carcinoma agents targeting VEGFR-2: Synthesis, In Vitro biological evaluation and molecular docking. Eur. J. Med. Chem. 2015, 100, 89-97. [CrossRef] [PubMed]

20. Eldehna, W.M.; Abou-Seri, S.M.; El Kerdawy, A.M.; Ayyad, R.R.; Hamdy, A.M.; Ghabbour, H.A.; Ali, M.M.; El Ella, D.A.A. Increasing the binding affinity of VEGFR-2 inhibitors by extending their hydrophobic interaction with the active site: Design, synthesis and biological evaluation of 1-substituted-4-(4-methoxybenzyl)phthalazine derivatives. Eur. J. Med. Chem. 2016, 113, 50-62. [CrossRef] [PubMed]

21. Eldehna, W.M.; Fares, M.; Ceruso, M.; Ghabbour, H.A.; Abou-Seri, S.M.; Abdel-Aziz, H.A.; El Ella, D.A.A.; Supuran, C.T. Amido/ureidosubstituted benzenesulfonamides-isatin conjugates as low nanomolar/subnanomolar inhibitors of the tumor-associated carbonic anhydrase isoform XII. Eur. J. Med. Chem. 2016, 110, 259-266. [CrossRef] [PubMed]

22. Abdel-Aziz, H.A.; Eldehna, W.M.; Ghabbour, H.; Al-Ansary, G.H.; Assaf, A.M.; Al-Dhfyan, A. Synthesis, crystal study, and anti-proliferative activity of some 2-benzimidazolylthioacetophenones towards triple-negative breast cancer MDA-MB-468 cells as apoptosis-inducing agents. Int. J. Mol. Sci. 2016, 17, 1221. [CrossRef] [PubMed]

23. Abdel-Aziz, H.A.; Ghabbour, H.A.; Eldehna, W.M.; Al-Rashood, S.T.; Al-Rashood, K.A.; Fun, H.K.; Al-Tahhan, M.; Al-Dhfyan, A. 2-((Benzimidazol-2-yl)thio)-1-arylethan-1-ones: Synthesis, crystal study and cancer stem cells CD133 targeting potential. Eur. J. Med. Chem. 2015, 104, 1-10. [CrossRef] [PubMed]

24. Eldehna, W.M.; Abo-Ashour, M.F.; Nocentini, A.; Gratteri, P.; Eissa, I.H.; Fares, M.; Ismael, O.E.; Ghabbour, H.A.; Elaasser, M.M.; Abdel-Aziz, H.A.; et al. Novel 4/3-((4-oxo-5-(2-oxoindolin-3-ylidene) thiazolidin-2-ylidene)amino)benzenesulfonamides: Synthesis, carbonic anhydrase inhibitory activity, anticancer activity and molecular modelling studies. Eur. J. Med. Chem. 2017, 139, 250-262. [CrossRef] [PubMed]

25. Al-Ansary, G.H.; Eldehna, W.M.; Ghabbour, H.A.; Al-Rashood, S.T.; Al-Rashood, K.A.; Eladwy, R.A.; Al-Dhfyan, A.; Kabil, M.M.; Abdel-Aziz, H.A. Cancer stem cells CD133 inhibition and cytotoxicity of certain 3-phenylthiazolo [3, 2-a] benzimidazoles: Design, direct synthesis, crystal study and In Vitro biological evaluation. J. Enzym. Inhib. Med. Chem. 2017, 32, 986-991. [CrossRef] [PubMed]

26. Mosmann, T. Rapid colorimetric assay for cellular growth and survival: Application to proliferation and cytotoxicity assays. J. Immunol. Methods 1983, 65, 55-63. [CrossRef]

27. Boyd MRand Paull, K.D. Some practical considerations and applications of the National Cancer Institute In Vitro anticancer drug discovery screen. Drug Dev. Res. 1995, 34, 91-109. [CrossRef]

28. Boyd, M.R. Cancer Drug Discovery and Development: Anticancer Drug Development Guide: Preclinical Screening, Clinical Trials and Approval; Teicher, B.A., Ed.; Humana Press: Totowa, NJ, USA, 2014; Chapter 1; pp. 41-62.

29. Monks, A.; Scudiero, D.; Skehan, P.; Shoemaker, R.; Paull, K.; Vistica, D.; Hose, C.; Langley, J.; Cronise, P.; Vaigro-Wolff, A.; et al. Feasibility of a high-flux anticancer drug screen using a diverse panel of cultured human tumor cell lines. J. Natl. Cancer Inst. 1991, 83, 757-766. [CrossRef] [PubMed]

30. Skehan, P.; Storeng, R.; Scudiero, D.; Monks, A.; McMahon, J.; Vistica, D.; Warren, J.T.; Bokesch, H.; Kenney, S.; Boyd, M.R. New colorimetric cytotoxicity assay for anticancer-drug screening. J. Natl. Cancer Inst. 1990, 82, 1107-1112. [CrossRef] [PubMed]

31. Lipinski, C.A.; Lombardo, F.; Dominy, B.W.; Feeney, P.J. Experimental and computational approaches to estimate solubility and permeability in drug discovery and development settings. Adv. Drug Deliv. Rev. 2012, 64, 4-17. [CrossRef]

32. Veber, D.F.; Johnson, S.R.; Cheng, H.-Y.; Smith, B.R.; Ward, K.W.; Kopple, K.D. Molecular properties that influence the oral bioavailability of drug candidates. J. Med. Chem. 2002, 45, 2615-2623. [CrossRef] [PubMed]

33. Eldehna, W.M.; Fares, M.; Abdel-Aziz, M.M.; Abdel-Aziz, H.A. Design, synthesis and antitubercular activity of certain nicotinic Acid hydrazides. Molecules 2015, 20, 8800-8815. [CrossRef] [PubMed]

34. Almahli, H.; Hadchity, E.; Jaballah, M.Y.; Daher, R.; Ghabbour, H.A.; Kabil, M.M.; Al-shakliah, N.S.; Eldehna, W.M. Development of novel synthesized phthalazinone-based PARP-1 inhibitors with apoptosis inducing mechanism in lung cancer. Bioorg. Chem. 2018, 77, 443-456. [CrossRef] [PubMed]

35. Eldehna, W.M.; EL-Naggar, D.H.; Hamed, A.R.; Ibrahim, H.S.; Ghabbour, H.A.; Abdel-Aziz, H.A. One-pot three-component synthesis of novel spirooxindoles with potential cytotoxic activity against triple-negative breast cancer MDA-MB-231 cells. J. Enzym. Inhib. Med. Chem. 2018, 33, 309-318. [CrossRef] [PubMed] 
36. Eldehna, W.M.; Abo-Ashour, M.F.; Ibrahim, H.S.; Al-Ansary, G.H.; Ghabour, H.A.; Elaasser, M.M.; Ahmed, H.Y.A.; Safwat, N.A. Novel [(3-indolylmethylene)hydrazono]indolin-2-ones as apoptotic anti-proliferativeagents: Design, synthesis and In Vitro biological evaluation. J. Enzym. Inhib. Med. Chem. 2018, 33, 686-700. [CrossRef] [PubMed]

37. Abou-Seri, S.M.; Eldehna, W.M.; Ali, M.M.; El Ella, D.A.A. 1-Piperazinylphthalazines as potential VEGFR-2 inhibitors and anticancer agents: Synthesis and In Vitro biological evaluation. Eur. J. Med. Chem. 2016, 107, 165-179. [CrossRef] [PubMed]

Sample Availability: Samples of the compounds $\mathbf{8 a}-\mathbf{n}$ are available from the authors.

(C) 2018 by the authors. Licensee MDPI, Basel, Switzerland. This article is an open access article distributed under the terms and conditions of the Creative Commons Attribution (CC BY) license (http:/ / creativecommons.org/licenses/by/4.0/). 